\title{
New particle formation in the marine atmosphere during seven cruise campaigns
}

\author{
Yujiao Zhu ${ }^{1}$, Kai $\mathrm{Li}^{2}$, Yanjie Shen ${ }^{1}$, Yang Gao ${ }^{1,3}$, Xiaohuan Liu ${ }^{1}$, Yang $\mathrm{Yu}^{1}$, Huiwang Gao ${ }^{1,3}$, and Xiaohong Yao ${ }^{1,3}$ \\ ${ }^{1}$ Key Lab of Marine Environmental Science and Ecology, Ministry of Education, \\ Ocean University of China, Qingdao 266100, China \\ ${ }^{2}$ National Marine Environmental Forecasting Center, Beijing 100081, China \\ ${ }^{3}$ Laboratory for Marine Ecology and Environmental Science, Qingdao National Laboratory \\ for Marine Science and Technology, Qingdao 266071, China
}

Correspondence: Xiaohong Yao (xhyao@ouc.edu.cn)

Received: 11 July 2018 - Discussion started: 30 July 2018

Revised: 6 December 2018 - Accepted: 7 December 2018 - Published: 3 January 2019

\begin{abstract}
We measured the particle number concentration, size distribution, and new particle formation (NPF) events in the marine atmosphere during six cruise campaigns over the marginal seas of China in 2011-2016 and one campaign from the marginal seas to the Northwest Pacific Ocean (NWPO) in 2014. We observed relatively frequent NPF events in the atmosphere over the marginal seas of China, i.e., on 23 out of 126 observational days, with the highest frequency of occurrence in fall, followed by spring and summer. In total, 22 out of 23 NPF events were found to be associated with the long-range transport of continental pollutants based on $24 \mathrm{~h}$ air mass back trajectories and pre-existing particle number concentrations, which largely exceeded the clean marine background, leaving one much weaker NPF event that was likely induced by oceanic precursors alone, as supported by multiple independent pieces of evidence. Although the longrange transport signal of continental pollutants can be clearly observed in the remote marine atmosphere over the NWPO, NPF events were observed on only 2 out of 36 days. The nucleation-mode particles $(<30 \mathrm{~nm})$, however, accounted for as high as $35 \% \pm 13 \%$ of the total particle number concentration during the NWPO cruise campaign, implying the existence of many undetected NPF events in the near-sea-level atmosphere or above.
\end{abstract}

To better characterize NPF events, we introduce a term called the net maximum increase in the nucleation-mode particle number concentration (NMINP) and correlate it with the formation rate of new particles (FR). We find a moderately good linear correlation between NMINP and FR at FR $\leq$
$8 \mathrm{~cm}^{-3} \mathrm{~s}^{-1}$, but no correlation exists at FR $>8 \mathrm{~cm}^{-3} \mathrm{~s}^{-1}$. The possible mechanisms are argued in terms of the roles of different vapor precursors. We also find that a ceiling exists for the growth of new particles from $10 \mathrm{~nm}$ to larger sizes in most NPF events. We thereby introduce a term called the maximum geometric median diameter of new particles $\left(D_{\text {pgmax }}\right)$ and correlate it with the growth rate of new particles (GR). A moderately good linear correlation is also obtained between the $D_{\text {pgmax }}$ and GR, and only GR values larger than $7.9 \mathrm{~nm} \mathrm{~h}^{-1}$ can lead to new particles growing with a $D_{\text {pgmax }}$ beyond $50 \mathrm{~nm}$ based on the equation. By combining simultaneous measurements of the particle number size distributions and cloud condensation nuclei $(\mathrm{CCN})$ at different super saturations (SS), we observed a clear increase in $\mathrm{CCN}$ when the $D_{\mathrm{pg}}$ of new particles exceeded $50 \mathrm{~nm}$ at $\mathrm{SS}=0.4 \%$. However, this case did not occur for $\mathrm{SS}=0.2 \%$. Consistent with the results of previous studies in the continental atmosphere, our results imply that particles smaller than $50 \mathrm{~nm}$ are unlikely activated as $\mathrm{CCN}$ at $\mathrm{SS}=0.4 \%$ in the marine atmosphere. Moreover, $\kappa$ decrease from 0.4 to 0.1 during the growth period of new particles, implying that organics likely overwhelm the growth of new particles to $\mathrm{CCN}$ size. The chemical analysis of nano-Micro-Orifice Uniform Deposit Impactor (nano-MOUDI) samples reveals that trimethylamine (TMA) and oxalic acid might appreciably contribute to the growth of new particles in some cases. 


\section{Introduction}

New particle formation (NPF) events have been widely studied in clean or polluted continental atmospheres, because these processes are considered to be an important source of atmospheric particles (Kulmala and Kerminen, 2008; Zhang et al., 2012; Sabaliauskas et al., 2012; Zhu et al., 2014; Kerminen et al., 2018). The growth of new particles in the atmosphere can affect Earth's radiation budget by acting as cloud condensation nuclei $(\mathrm{CCN})$ or directly scattering and absorbing solar radiation (Kerminen et al., 2012; Seinfeld and Pandis, 2012). The ocean is the largest source of moisture on Earth, and NPF events in the marine atmosphere are important because of their potential indirect climate effects. Kazil et al. (2010) reported that the contribution of atmospheric nucleation processes to the total absorbed solar shortwave radiation was $-2.18 \mathrm{~W} \mathrm{~m}^{-2}$ over oceans, which was 7 times larger than that over continents.

In the clear marine atmosphere, oxidation products of dimethyl sulfide (DMS) and iodine compounds, together with reactive amines, are generally considered to be the important biogenic precursors of the nucleation and growth of newly formed particles (e.g., Charlson et al., 1987; O'Dowd and de Leeuw, 2007; Quinn and Bates, 2011; Sellegri et al., 2016). Over the past 3 decades, many observational and modeling studies have been conducted to investigate the roles of DMS in NPF events in various marine atmospheres and the related effects on the climate (e.g., Charlson et al., 1987; Ayers and Gras, 1991; Hegg et al., 1991; Yu and Luo, 2010; Chang et al., 2011; Lana et al., 2012). The responses of grown new particles and clouds to marine biogenic products are much more complex than those derived from DMS (Quinn and Bates, 2011). NPF events induced by iodine species were frequently observed at coastal locations, most notably at Mace Head on the western coast of Ireland, in the presence of enhanced biological emissions during low tides and during ocean upwelling or sea-ice melting conditions (O'Dowd et al., 2002a, b; Wen et al., 2006; O'Dowd and de Leeuw, 2007; Ehn et al., 2010; Huang et al., 2010; McFiggans et al., 2010; Allan et al., 2015; Sellegri et al., 2016; Sipilä et al., 2016). Moreover, amines, which can be produced through excretion and metabolism by a variety of marine organisms, were reported to enhance $\mathrm{H}_{2} \mathrm{SO}_{4}-\mathrm{H}_{2} \mathrm{O}$ nucleation and promote the growth of newly formed particles (Ge et al., 2011; Zhang et al., 2012; Yu et al., 2016; Olenius et al., 2017). Observations in the eastern Pacific Ocean revealed that an increase in the gaseous precursors of amines and DMS affected the particulate chemical composition and cloud properties (Sorooshian et al., 2009). Lab studies have shown that the reactions of methanesulfonic acid (MSA) and amines can generate new particles, even in the absence of sulfuric acid (Chen et al., 2015a, b; Arquero et al., 2017).

Moderate cloud water-vapor super saturations (SS) are approximately $0.2 \%$ in the marine boundary layer (MBL), requiring the minimum diameter of $70-80 \mathrm{~nm}$ to be activated into CCN (Hoppel et al., 1996; Petters and Kreidenweis, 2007; Seinfeld and Pandies, 2012). In the atmosphere over the eastern Mediterranean during summer, newly formed particles can grow to approximately $100 \mathrm{~nm}$ within a few hours because of the clean air masses abundant with $\mathrm{H}_{2} \mathrm{SO}_{4}$ vapor from high altitudes, and the number concentration of $\mathrm{CCN}$ is substantially increased (Kalkavouras et al., 2017). In some iodine-related NPF events, newly formed particles can also grow up to approximately $100 \mathrm{~nm}$ within a few hours, significantly contributing to the CCN concentration (O'Dowd et al., 2002b). However, no obvious growth of new particles was observed in a large number of iodine-related NPF events that were classified as local NPF events (Wen et al., 2006; Vana et al., 2008; Ehn et al., 2010). Some previous cruise measurements in open oceans showed that NPF events were rarely observed and did not significantly contribute to the CCN concentration (Covert et al., 1996; Ueda et al., 2016).

Unlike in the clear marine atmosphere, the oxidation products of air pollutants such as $\mathrm{SO}_{2}, \mathrm{NO}_{x}$, and anthropogenic volatile organic compounds might also be involved in NPF events in polluted marine atmospheres (Pikridas et al., 2012; Liu et al., 2014; Peng et al., 2014; Guo et al., 2016). Theoretically continental air pollutants and marine biogenic precursors may interact with each other and affect the formation and growth of new particles. The differences among NPF events in the marine atmosphere driven by the longrange transport of continental pollutants, ocean-derived biogenic precursors, and a combination of both, are poorly understood.

In this study, we investigate NPF events during seven cruise campaigns covering three seasons, including spring, summer, and fall, over the marginal seas of China (including the Bohai Sea - BS, northern Yellow Sea - NYS, southern Yellow Sea-SYS, and East China Sea-ECS) to the Northwest Pacific Ocean (NWPO). When the summer Asian monsoon prevails, the wind direction is mostly from the sea to the land in the daytime, increasing the probability of successfully observing NPF events associated with ocean-derived precursors. Spring and fall are the transition periods between the summer and winter Asian monsoons. NPF events during these campaigns could be related to ocean-emitted and/or continent-transported precursors and will be used for comparison. In addition, a measurement at a coastal site was performed alongside the marine measurements during three campaigns to identify simultaneously occurring NPF events and reveal the similarities and differences between them in marine and coastal atmospheres. All NPF events in the marine atmosphere and supporting observations in the coastal atmosphere are analyzed in terms of the frequency of occurrence, formation rates and growth rates of new particles, the maximum increase in the new particle number concentration, the maximum size of grown new particles, the new particle survival probability to $\mathrm{CCN}$ sizes, possible chemicals driving the new particle growth, etc. 

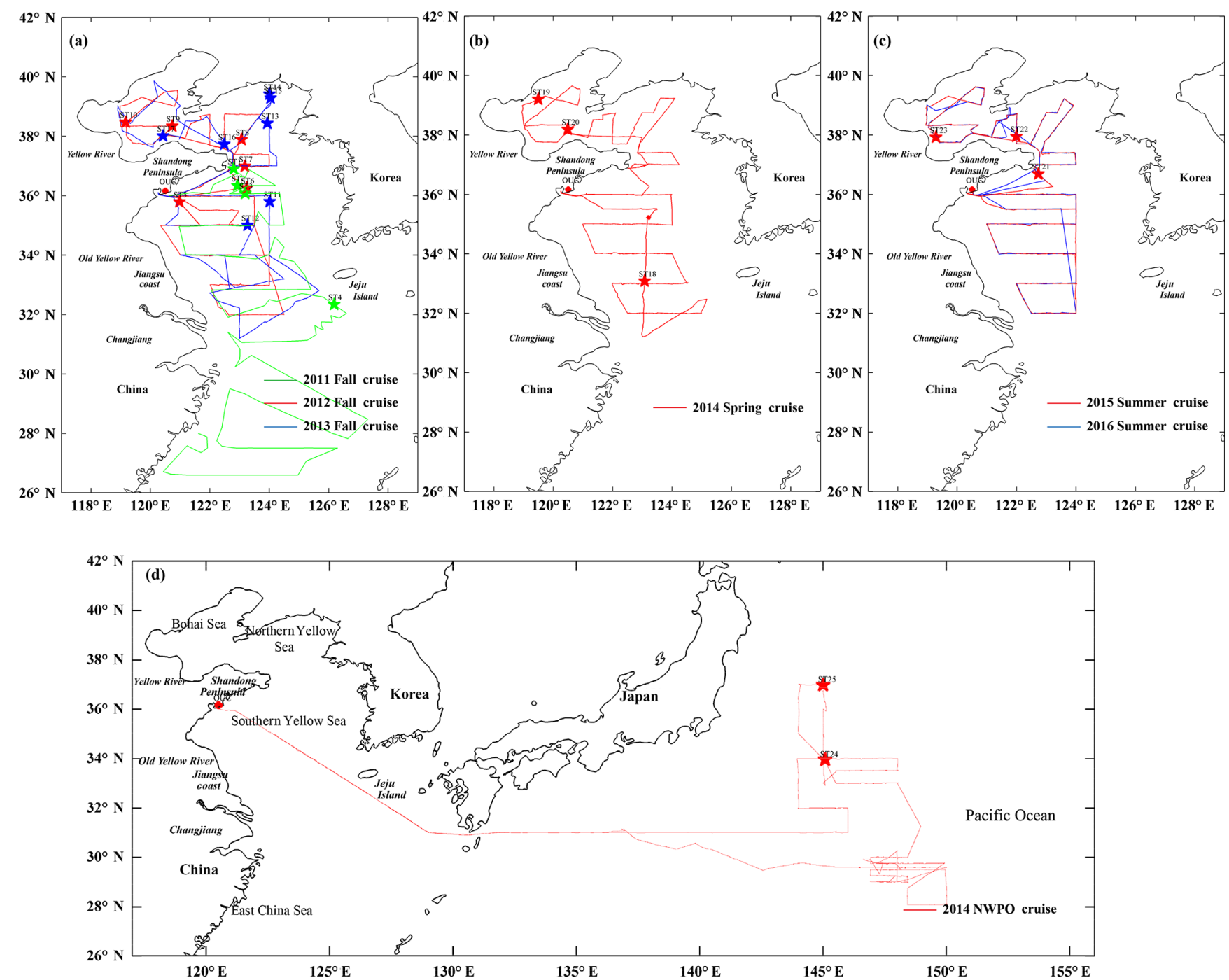

Figure 1. Cruise track over the marginal seas of China and NWPO (a: fall cruises from 16 October to 5 November 2011, 2-20 November 2012, and 5-25 November 2013; (b): spring cruise from 28 April to 19 May 2014; (c): summer cruises from 18 August to 5 September 2015 and from 28 June to 20 July 2016; (d): NWPO cruise from 18 March to 22 April 2014; the stars represent the ship location during NPF events).

\section{Experimental design}

\subsection{Cruise description and sampling methods}

Measurements were made in six cruise campaigns across the marginal seas of China, including the BS, the NYS, the SYS, and the ECS (Fig. 1a-c) on 16 October to 5 November 2011, 2-20 November 2012, 5-25 November 2013, 28 April to 19 May 2014, 18 August to 5 September 2015, and 28 June to 20 July 2016 . The level of air pollutants, as indicated by the $\mathrm{NO}_{2}$ column densities in the researched sea areas, showed clear seasonal variations (Fig. S1). In November 2012, the elevated $\mathrm{NO}_{2}$ column densities in the eastern mainland of China were likely caused by multiple factors, such as intensive house heating and poorer dispersive conditions. The higher $\mathrm{NO}_{2}$ column densities subsequently affected the downwind marine atmospheres through continental outflow, which was driven by the Asian monsoon (Fig. S1a). In May 2014, the atmosphere in the marginal seas also received continental pollutants to a small extent (Fig. S1b). When the summer Asian monsoon prevailed in August, a clean atmosphere generally occurred over the marginal seas (Fig. S1c). On 18 March to 22 April 2014, we made measurements from the marginal seas to the NWPO in which the $\mathrm{NO}_{2}$ column densities showed a clean atmosphere, particularly over the NWPO (Fig. S1d).

During each cruise campaign, a Fast Mobility Particle Sizer (FMPS; TSI Model 3091) was set up on the sixth floor of Dongfanghong 2, approximately $15 \mathrm{~m}$ above sea level. The FMPS was downstream of a dryer, and continu- 
ously measured particle number concentrations ranged from 5.6 to $560 \mathrm{~nm}$ in 32 channels in $1 \mathrm{~s}$ time resolution. The FMPS was used because its high time resolution can successfully isolate of the interference associated with ship selfemissions and identify the growth of newly formed particles from the mixing of newly formed particles and preexisting particles (Liu et al., 2014; Man et al., 2015). However, FMPS has been reported to underestimate the particle size compared to the scanning mobility particle sizer (SMPS) and high-resolution time-of-flight aerosol mass spectrometer (HR-ToF-AMS; Lee et al., 2013). In this study, the FMPS data were corrected based on a condensation particle counter (CPC; TSI Model 3775) by using the method by Zimmerman et al. (2015). A cloud condensation nuclei counter (CCNC; DMT) was set up near the FMPS during the four cruise campaigns in 2014-2016. The CCNC was operated at a total flow rate of $0.45 \mathrm{~L} \mathrm{~min}^{-1}$, with five different SS values set at $0.2 \%, 0.4 \%, 0.6 \%, 0.8 \%$, and $1.0 \%$. A 14 stage nano-Micro-Orifice Uniform Deposit Impactor (nanoMOUDI; Models 122-NR) equipped with Teflon filters in the upper 11 stages and Zefluor filters in the remaining three stages was set up near the FMPS during the six campaigns in the years 2012 to 2016 . The $50 \%$ cutoff points for particle aerodynamic diameters were $18,10,5.6,3.2,1.8,1.0$, $0.56,0.32,0.18,0.1,0.056,0.032,0.018$, and $0.010 \mu \mathrm{m}$. Alternatively, when the nano-MOUDI was unavailable, an 11stage MOUDI (Models 110-II ${ }^{\mathrm{TM}}$ ) with cutoff sizes from 18 to $0.056 \mu \mathrm{m}$ was used instead. The air pump of the MOUDI or nano-MOUDI was switched on only when the ship was sailing, and the sampling duration was approximately $10-12 \mathrm{~h}$ per day to accumulate sufficient mass for chemical analysis. Inorganic ions, aminium ions, and dicarboxylic acids were detected, and the chemical analysis method followed $\mathrm{Hu}$ et al. (2015) and Teng et al. (2017); details can be found in Sect. S1 in the Supplement.

The coastal measurements were conducted at the campus of the Ocean University of China (OUC; $36^{\circ} 9^{\prime} 37^{\prime \prime} \mathrm{N}$, $120^{\circ} 29^{\prime} 44^{\prime \prime}$ E; red circle in Fig. 1) alongside the three cruise campaigns on 2-20 November 2012, 5-25 November 2013 and 18 August to 5 September 2015. The sampling site at the OUC was approximately $7 \mathrm{~km}$ from the nearest coastline of the southern Yellow Sea. A NanoScan SMPS nanoparticle sizer (nano-SMPS; TSI, 3910) was placed on the fifth floor of an academic building ( $\sim 15 \mathrm{~m}$ above ground level) and continuously measured the number concentrations of particles ranging from 10 to $420 \mathrm{~nm}$ in 13 channels, with a 1 min time resolution. The two particle sizers, the FMPS and nano-SMPS, were operated side by side for comparison on 14-25 October 2012. The determination coefficients $\left(R^{2}\right)$ of the particle number concentrations between these devices were in the range of 0.7-0.9. Figure $\mathrm{S} 2$ shows the comparison results for the 4 NPF days. The number concentration of nucleation-mode particles $\left(N_{<30 \mathrm{~nm}}\right)$ from the FMPS was higher than that from the nano-SMPS, especially during the initial NPF time, further leading to the calculated new particle formation rate (FR) from FMPS was $0.2-0.8$ times larger than that from the nano-SMPS (Table S1). This difference could also have been caused by the different size detection limits, i.e., $5.6 \mathrm{~nm}$ for FMPS and $10 \mathrm{~nm}$ for nanoSMPS. When particles with diameters smaller than $10 \mathrm{~nm}$ were excluded from calculation, the particle number concentrations between 10-30 nm from the FMPS matched well with those from the nano-SMPS. The FRs calculated from the data between the two instruments had a difference within $20 \%$ (Fig. S2 and Table S1). In this study, particles smaller than $10 \mathrm{~nm}$ were included to calculate the FR for the data from the FMPS, unless otherwise specified. In addition, the fitted geometric median diameter of new particles $\left(D_{\mathrm{pg}}\right)$ between the two devices showed good correlations when newly formed particles exhibited obvious growth. The calculated growth rates from the data between the two instruments had a difference within $20 \%$.

\subsection{Definition of NPF events and calculation methods}

NPF events can be identified based on the criteria proposed by Dal Maso et al. (2005), Hirsikko et al. (2007), and Kulmala et al. (2012): (1) a new mode of particles, i.e., a nucleation mode $<30 \mathrm{~nm}$, must be observed, (2) the new mode must prevail over a time span, and (3) the new mode must grow to be observable. These three criteria enable us to distinguish NPF events from ship emissions and air pollutant plumes. Moreover, Kulmala et al. (2012) recently summarized the protocol for measurements of NPF events and referred to regional NPF events as those events occurring in a spatial extent that varies from tens to thousands of kilometers. According to this definition, the NPF events observed over the marginal seas were confirmed as regional events, except for the NPF event on 15 May 2014. The evidence indicates that (1) the duration of the NPF events exceeded $3 \mathrm{~h}$ on 22 days out of the total of 23 days over the marginal seas of China and (2) on-board observations were made mostly during traveling instead of when anchored at fixed locations. The ship traveled at a speed of $18 \mathrm{~km} \mathrm{~h}^{-1}$. A rough calculation of the spatial span is $18 \mathrm{~km} \mathrm{~h}^{-1} \times \mathrm{NPF}$ time in hours for the NPF events over the sea. The NPF event on 15 May 2014 appeared to last for about $1 \mathrm{~h}$, because the ship emissions overwhelmed the new particle signal after 09:30.

The FR, growth rate (GR), and condensation sink (CS) were calculated, and the methods are detailed in Sect. S2. The net maximum increase in the nucleation-mode particle number concentration (NMINP) was defined as $N_{<30 \mathrm{~nm}}$ at the time of reaching the maximal value minus $N_{<30} \mathrm{~nm}$ at the time immediately before the apparent NPF was initiated (Zhu et al., 2017). The CCN activation ratio (AR), i.e., the number fraction of the atmospheric aerosol particles (condensation nuclei - $\mathrm{CN}$ ) activated to the $\mathrm{CCN}$ at a given SS, was estimated by the following equation:

$\mathrm{AR}(\mathrm{SS})=N_{\mathrm{CCN}} / N_{\mathrm{CN}}$ 
Here, $N_{\mathrm{CCN}}$ is the number concentration of $\mathrm{CCN}$ measured by the CCNC, and $N_{\mathrm{CN}}$ is the total particle number concentration measured by the FMPS.

The mass concentrations of nanoparticles were calculated by using the corrected FMPS data. The electrical mobility diameter was converted into the aerodynamic diameter following the equation of Khlystov et al. (2004), and the density of the particles was assumed to be $1.5 \mathrm{~g} \mathrm{~cm}^{-3}$. Air mass back trajectories were calculated by using the Hybrid Single Particle Lagrangian Integrated Trajectory (HYSPLIT) model with REANALYSIS meteorological data. The times indicated in this paper are in local time, i.e., UTC +8 over the marginal seas of China and UTC +10 at the locations of the 2 NPF days over the NWPO.

\section{Results}

\subsection{Occurrence of NPF events in the marine atmosphere}

During the seven cruise campaigns, NPF events were observed on 25 days out of the total of 162 observational days (Tables 1 and A1, Fig. A1; Liu et al., 2014). All NPF events were initially observed at 07:00-12:00 in the morning on sunny days. In the atmosphere over the marginal seas of China, the occurrence frequency of NPF events was the highest in fall $(28 \%)$, followed by spring (14\%) and summer (7\%). In contrast, spring was widely documented as the season with the highest frequency of occurrence for NPF events in the continental boundary layer globally (Kulmala et al., 2004; Zhu et al., 2014; Wang et al., 2017; Nieminen et al., 2018). Spring is characterized by the most frequent occurrence of sea fog over the marginal seas, likely resulting from the slower warming of the sea surface relative to the surrounding air (Roach et al., 1995; Cho et al., 2000), leading to high relative humidity in the MBL and the subsequent prevention of NPF occurrence. During the summer campaign, NPF events were rarely observed. Compared to the marginal seas of China, the cruise over the NWPO during the spring of 2014 showed much fewer NPF event occurrences, i.e., on 2 out of 36 days.

As explained in Sect. 2.1, simultaneous measurements at the coastal site (OUC) were conducted during three cruise periods for a total of 59 days in 2012, 2013, and 2015. NPF events were observed on 16 sunny days out of the total 59 days (right panels in Fig. A1). Simultaneous observations of NPF events at the coastal site on the same day further zoom regional NPF events into simultaneous NPF events, i.e., NPF events occurring on a line over dozens of kilometers in the marginal sea and at the additional coastal site. These simultaneous NPF events are a subset of regional NPF events, and the types of NPF events have been claimed based on several sets of measurements over a large spatial range in the literature (e.g., Hussein et al., 2009; Jeong et al., 2010; Wang et al., 2013; Shen et al., 2018). In this study, simultaneous NPF events were observed on 5 days during the fall campaign in 2012, 6 days during the fall campaign in 2013, and only 1 day during the summer campaign in 2015. Based on the distance between the OUC and the ship location at the time of occurrence, we roughly estimated the spatial scale for simultaneous NPF events as at least $50-500 \mathrm{~km}$. In each simultaneous NPF event, the NPF started $15 \mathrm{~min}-3 \mathrm{~h}$ earlier in the marine atmosphere than at the OUC site. Theoretically, the concentration of precursor vapors is an important factor in determining the occurrence of NPF events. Unfortunately, we did not measure these condensable vapors in this study. The CS indirectly affects the NPF process through removing condensation vapors and may contribute to the delay. For example, the delays in the coastal atmosphere on 17 November 2012 and 7 November 2013 were very likely caused by the presence of stronger condensational sinks (Fig. A1h, i, 1, m). Many other factors, such as weather conditions which can affect the concentrations of precursor vapors and gas-aerosol partitioning, and the downward transportation of nanoparticles, might also contribute to such delays. The occurrence frequencies of NPF events during the two fall marine campaigns were similar to those in the coastal atmosphere at the OUC site, but the frequency during the summer marine campaign was much lower. The marine atmosphere is quite clear in summer because of the summer Asian monsoon.

\subsection{Particle number concentrations and size distributions in the presence of NPF events against the background atmosphere in marine atmospheres}

To compare the particle number concentrations and size distributions in the presence of NPF events with those in the background atmosphere, we first classified the observational data into two categories. Category 1 represents background particle signals during the periods with neither NPF events nor ship emissions. Category 2 represents atmospheric particle signals in the presence of NPF events, with the ship emission periods removed. The ship-emitted particles can be clearly identified in the high-time-resolution measurements. First, ship-emitted particles exhibited a unimodal size distribution at $10-60 \mathrm{~nm}$ with a peak at $20-30 \mathrm{~nm}$. Only a small variation existed in the particle number size distribution, depending on the weather conditions. Second, the number concentration of the ship-emitted particles was an order of magnitude higher than that of the background particles and new particles. Third, dozens to hundreds of spikes were present in the particle number concentration when ship-emitted particle signals were detected. For Categories 1 and 2, the average particle number concentration spectra were derived for the marginal seas of China, the NWPO, and the OUC (Fig. 2).

We first discuss the Category 1 data over the marginal seas of China and the NWPO. The average total particle number concentration was $0.8 \pm 0.5 \times 10^{4}$ particles $\mathrm{cm}^{-3}$ in the atmosphere over the marginal seas of China (dashed black 
Table 1. Summary of the NPF frequency, FR, GR, CS, NMINP, and $D_{\text {pgmax }}$ over the marginal seas of China, over NWPO, and at the OUC site.

\begin{tabular}{|c|c|c|c|c|c|c|c|c|}
\hline Campaigns & Location & Frequency & $\begin{array}{r}\mathrm{FR} \\
\left(\mathrm{cm}^{-3} \mathrm{~s}^{-1}\right)\end{array}$ & $\begin{array}{r}\text { GR } \\
\left(\mathrm{nm} \mathrm{h}^{-1}\right)\end{array}$ & $\begin{array}{r}\mathrm{CS} \\
\left(10^{-2} \mathrm{~s}^{-1}\right)\end{array}$ & $\begin{array}{r}\text { NMINP } \\
\left(10^{4} \mathrm{~cm}^{-3}\right)\end{array}$ & $\begin{array}{r}D_{\text {pgmax }} \\
(\mathrm{nm})\end{array}$ & $\begin{array}{l}\text { Simultaneous } \\
\text { NPF event }\end{array}$ \\
\hline \multicolumn{9}{|l|}{ Fall cruise } \\
\hline $\begin{array}{l}16 \text { October- } \\
15 \text { November } 2011\end{array}$ & $\begin{array}{l}\text { Marginal } \\
\text { seas }\end{array}$ & $\begin{array}{l}28 \% \\
(17 / 61 \text { days })\end{array}$ & $5.3 \pm 5.4$ & $3.5 \pm 2.1$ & $0.8 \pm 0.3$ & $1.6 \pm 1.0$ & 50 & \multirow[t]{2}{*}{11 days } \\
\hline $\begin{array}{l}\text { 2-20 November } 2012 \\
\text { 5-25 November } 2013\end{array}$ & OUC & $\begin{array}{l}30 \% \\
(12 / 40 \text { days })\end{array}$ & $2.4 \pm 1.1$ & $4.3 \pm 2.2$ & $4.1 \pm 2.1$ & $0.9 \pm 0.4$ & 100 & \\
\hline \multicolumn{9}{|l|}{ Summer cruise } \\
\hline $\begin{array}{l}18 \text { August- } \\
5 \text { September } 2015\end{array}$ & $\begin{array}{l}\text { Marginal } \\
\text { seas }\end{array}$ & $\begin{array}{l}7 \% \\
\text { (3/43 days) }\end{array}$ & $10.5 \pm 9.3$ & $7.3 \pm 4.9$ & $2.7 \pm 0.7$ & $1.4 \pm 1.1$ & 77 & \multirow[t]{2}{*}{1 day } \\
\hline $\begin{array}{l}28 \text { June-- } \\
20 \text { July } 2016\end{array}$ & OUC & $\begin{array}{l}22 \% \\
(4 / 18 \text { days })\end{array}$ & $3.2 \pm 2.3$ & $11.3 \pm 6.8$ & $1.2 \pm 0.3$ & $0.5 \pm 0.3$ & 45 & \\
\hline \multicolumn{9}{|l|}{ Spring cruise 1} \\
\hline $\begin{array}{l}28 \text { April- } \\
19 \text { May } 2014\end{array}$ & $\begin{array}{l}\text { Marginal } \\
\text { seas }\end{array}$ & $\begin{array}{l}14 \% \\
(3 / 22 \text { days })\end{array}$ & $6.9 \pm 3.8$ & $4.2 \pm 2.2$ & $2.0 \pm 0.5$ & $1.8 \pm 1.2$ & 50 & \\
\hline \multicolumn{9}{|l|}{ NWPO cruise } \\
\hline $\begin{array}{l}18 \text { March- } \\
22 \text { April } 2014\end{array}$ & NWPO & $\begin{array}{l}6 \% \\
(2 / 36 \text { days })\end{array}$ & $15.7 \pm 7.9$ & $15.0 \pm 16.1$ & $1.3 \pm 0.9$ & $1.3 \pm 0.5$ & 14 & \\
\hline \multicolumn{9}{|l|}{ Average all } \\
\hline & $\begin{array}{l}\text { Marginal } \\
\text { seas+ } \\
\text { NWPO }\end{array}$ & $\begin{array}{l}15 \% \\
(25 / 162 \text { days })\end{array}$ & $6.4 \pm 5.8$ & $4.7 \pm 4.7$ & $1.3 \pm 0.9$ & $1.6 \pm 0.9$ & 77 & \multirow[t]{2}{*}{12 days } \\
\hline & OUC & $\begin{array}{l}29 \% \\
(17 / 59 \text { days })\end{array}$ & $2.7 \pm 1.5$ & $6.1 \pm 4.8$ & $3.2 \pm 2.2$ & $0.8 \pm 0.4$ & 100 & \\
\hline
\end{tabular}

a: condensation sink (CS) that was averaged $1 \mathrm{~h}$ prior to the NPF events.

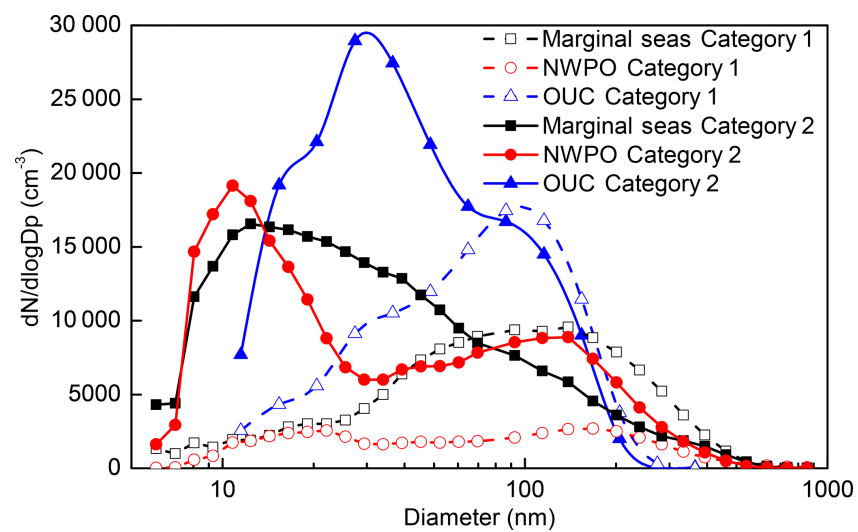

Figure 2. Average particle number size distributions in the atmospheres over the marginal seas of China, over NWPO, and at the OUC site (Category 1 represents background particle signals, and Category 2 represents new particle signals).

lines in Fig. 2). The Aitken mode (30-100 nm) and accumulation mode $(100-500 \mathrm{~nm})$ usually overlapped at the size range of 30-500 $\mathrm{nm}$, with a minor nucleation mode at sizes below $30 \mathrm{~nm}$. The contribution of the Aitken-mode particles to the total particle number concentration relative to that of the accumulation-mode particles greatly varied in different campaigns (not shown). Compared to the marginal seas of China, the total particle number concentrations decreased to $0.3 \pm 0.1 \times 10^{4}$ particles $\mathrm{cm}^{-3}$ over the NWPO because of a large drop in the number concentrations of particles with diameters larger than $20 \mathrm{~nm}$. This decrease was likely caused by combined contributions from dry and wet deposition, cloud processing and coagulation, etc. during the longrange transport of atmospheric particles from the marginal seas or the continents to open oceans (Hoppel et al., 1986; Guo et al., 2016; Luo et al., 2018). The $N_{<30 \mathrm{~nm}}$ over the NWPO $\left(0.12 \times 10^{4}\right.$ particles $\left.\mathrm{cm}^{-3}\right)$ was relatively comparable to, albeit slightly lower than, that over the marginal seas $\left(0.17 \times 10^{4}\right.$ particles $\left.\mathrm{cm}^{-3}\right)$. However, the percentage contribution of nucleation-mode particles to the total particle number concentration over the NWPO (35\%) was much larger than that over the marginal seas $(20 \%)$, indicating the important role of nucleation-mode particles as a source of at- 
mospheric particles over the NWPO. The observed high percentage of $N_{<30 \mathrm{~nm}}$ over NWPO was primarily a result of either direct generation in the MBL or downward transport from high altitudes such as the free troposphere (Clarke et al., 1998; Kulmala and Kerminen, 2008; Meng et al., 2015; Ueda et al., 2016). In the Category 1 data from the OUC site, the size distribution of the average particle number concentration was similar to that in the atmosphere over the marginal seas of China. For example, the Aitken-mode and accumulationmode particles accounted for approximately $80 \%$ of the total particle number concentration. However, the average particle number concentration of $1.4 \pm 0.8 \times 10^{4}$ particles $\mathrm{cm}^{-3}$ at the OUC site increased by 1 fold compared to that over the marginal seas of China and approximately 4 fold compared to that over the NWPO.

Compared to Category 1, NPF events greatly enhanced the total particle number concentrations (Fig. 2, solid lines) in Category 2 over the NWPO, over the marginal seas of China, and at the OUC site, mostly because of a large increase in the number concentration of newly formed particles. Over the NWPO, the increase in concentration of newly formed particles was limited to particles with diameters lower than $30 \mathrm{~nm}$, possibly because the growth pathways of newly formed particles were different from those at the OUC site and over the marginal seas, where newly formed particles could grow to diameters of $60 \mathrm{~nm}$. The $N_{<30 \mathrm{~nm}}$ of $0.9 \pm 0.6 \times 10^{4}$ particles $\mathrm{cm}^{-3}$ over the NWPO was higher than that reported in previous studies in open seas (Covert et al., 1996; Ueda et al., 2016) and accounted for $60 \%$ of the total particle number concentration. This increase was likely induced by the long-range transport of air pollutants from the continents, as inferred from the doubled number concentrations of accumulation-mode particles in Category 2 relative to Category 1 . Over the marginal seas of China, the average total particle number concentration was $1.6 \pm 1.1 \times 10^{4}$ particles $\mathrm{cm}^{-3}$, which was slightly smaller than that at the OUC site $\left(2.5 \pm 0.8 \times 10^{4}\right.$ particles $\left.\mathrm{cm}^{-3}\right)$, showing a comparable net increase, referred to as the arithmetic difference between Category 2 and Category 1. In addition, the average particle number size distributions over the marginal seas of China showed seasonal differences, i.e., a sharp peak occurring at particle sizes less than $20 \mathrm{~nm}$ in spring, a broad peak occurring in the particle size range of 7$50 \mathrm{~nm}$ in fall, and an even broader peak in the size range of 10 to $70 \mathrm{~nm}$ in summer (Fig. S3b). The results were caused by varying size ceilings in the growth of newly formed particles, i.e., the growth of newly formed particles apparently stopped when they grew to the maximum sizes during these events. For example, Fig. A1a, b show ceilings of approximately 50 $\mathrm{nm}$, and Fig. A1c, d show ceilings of approximately $20 \mathrm{~nm}$ during the events over the marginal seas and at the OUC site. In fact, a size ceiling is a common phenomenon during NPF events in various urban or coastal atmospheres, as highlighted by Zhu et al. $(2014,2017)$ and Man et al. (2015). These authors also proposed that the size ceiling is associated with the thermodynamic partitioning of semi-volatile species in growing newly formed particles.

\subsection{FR, GR, NMINP and $D_{\text {pgmax }}$ in marine atmosphere}

A total of four metrics were applied to evaluate the NPF events, including two commonly used parameters (FR and GR) and two other parameters, with one (NMINP) developed in our previous study (Zhu et al., 2017) and the other (maximum $D_{\text {pg }}, D_{\text {pgmax }}$ ) developed in this study. When we performed the calculations, ship emission periods were removed based on the three features mentioned in Sect. 3.1.

In the atmosphere over the marginal seas of China, large variations in FRs and GRs were observed during the three seasons (Tables 1 and A1), with those in summer larger than those in spring and fall. For example, among the total of three NPF events in summer, larger FRs and GRs were observed on 2 days, at $18.5 \mathrm{~cm}^{-3} \mathrm{~s}^{-1}$ and $9.6 \mathrm{~nm} \mathrm{~h}^{-1}$ on 27 August 2015 and $12.7 \mathrm{~cm}^{-3} \mathrm{~s}^{-1}$ and $10.6 \mathrm{~nm} \mathrm{~h}^{-1}$ on 4 September 2015 , respectively, with much smaller values $\left(0.3 \mathrm{~cm}^{-3} \mathrm{~s}^{-1}\right.$ and $1.7 \mathrm{~nm} \mathrm{~h}^{-1}$ ) on 30 August 2015, likely induced by precursors from marine sources. The high FRs and GRs in summer were reported to be induced by enhanced photochemical reactions from strong solar radiation (Kulmala et al., 2004; Wang et al., 2017). Large differences were found between the two observed NPF events over the NWPO, with $26.3 \mathrm{~nm} \mathrm{~h}^{-1}$ on 8 April 2014 and $3.6 \mathrm{~nm} \mathrm{~h}^{-1}$ on 13 April 2014. The high GR on 8 April 2014 was concurrent with a high FR $\left(11.8 \mathrm{~cm}^{-3} \mathrm{~s}^{-1}\right)$. Unfortunately, no FR was available on the low GR day (13 April 2014) because of the intermittent occurrence of nucleation. The GR and FR observed here were much higher than those observed in previous studies over the subtropical Pacific area (Ueda et al., 2016). We will return to these NPF events in Sect. 4.2. When considering both the marginal seas and the NWPO, the FR and GR did not show a significant negative correlation with the CS (Fig. S4).

The coastal experiments at the OUC were designed to simultaneously measure particles alongside the cruises over the marginal seas, so we next compare the simultaneous NPF events between the OUC and the marginal seas during the three campaigns. Note that only atmospheric particles with diameters larger than $10 \mathrm{~nm}$ over both the OUC and the marginal seas were used to compare FRs and GRs here because of the detection limit of the nano-SMPS. The FRs over the marginal seas $\left(5.5 \pm 5.6 \mathrm{~cm}^{-3} \mathrm{~s}^{-1}\right)$ displayed larger mean values and variations relative to those at the OUC site (2.2 \pm $\left.0.7 \mathrm{~cm}^{-3} \mathrm{~s}^{-1}\right)$, whereas comparable GRs were observed at the OUC $\left(6.1 \pm 4.8 \mathrm{~nm} \mathrm{~h}^{-1}\right)$ and over the marginal seas $(4.7 \pm$ $4.7 \mathrm{~nm} \mathrm{~h}^{-1}$ ). Compared to the OUC, the larger FRs over the marginal seas could be due to the lower number concentration of pre-existing particles and the associated smaller CS values. During simultaneous NPF events, the CS values over the marginal seas were $1.1 \pm 1.0\left(10^{-2} \mathrm{~s}^{-1}\right)$, much lower than those at the OUC site at $4.1 \pm 2.0\left(10^{-2} \mathrm{~s}^{-1}\right)$. However, no significant negative correlation between the FR and CS was 

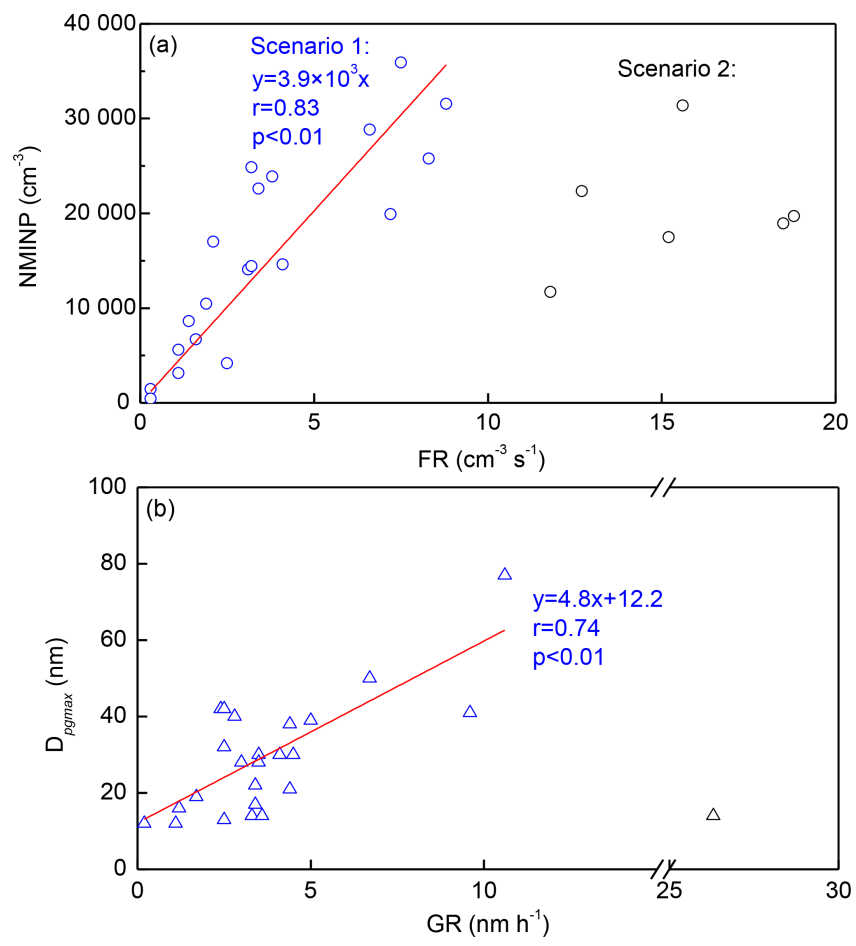

Figure 3. Relationship between the new particle formation rate (FR) and net maximum increase in the nucleation-mode particle number concentration (NMINP), growth rate (GR), and maximum geometric median diameter of new particles $\left(D_{\text {pgmax }}\right)$ in NPF events over the marginal seas of China and NWPO (the black shapes were treated as outliers, i.e., greater than 3 standard deviations from the regression curve, and were excluded from the correlation analysis).

observed (solid squares in Fig. S4). This effect could also have been caused by higher loadings of precursors that favored the new particle formation. These precursors, such as sulfuric acid, amines, and extremely low-volatility organic vapors, were reported to dominate the formation and initial growth of new particles (Paasonen et al., 2010; Ehn et al., 2014). In contrast, the different GRs between the marginal seas and the OUC could have been related to the availability of semi-volatile precursors, which promote the growth of larger new particles (Yao et al., 2010; Riipinen et al., 2012).

The NMINP varied from $438 \mathrm{~cm}^{-3}$ to $3.6 \times 10^{4} \mathrm{~cm}^{-3}$ in the marine atmosphere, but no obvious seasonal variations were observed, as discussed previously regarding the FR and GR (Table A1). Over the marginal seas and the NWPO, the NMINP and FR showed a moderately good linear correlation when the FRs were smaller than $8 \mathrm{~cm}^{-3} \mathrm{~s}^{-1}$, with $r=0.83$ and $p<0.01$ (Fig. 3a), but no correlation existed when the FRs exceeded $8 \mathrm{~cm}^{-3} \mathrm{~s}^{-1}$. This difference is argued as follows.

We define a technical term that refers to the total consumed amount of $\mathrm{H}_{2} \mathrm{SO}_{4}$ vapor for NPF. As reported in the literature, FR was controlled by the concentration of both $\mathrm{H}_{2} \mathrm{SO}_{4}$ vapor and organic vapor, i.e.,
$\mathrm{FR}=k_{\mathrm{NucOrg}}\left[\mathrm{H}_{2} \mathrm{SO}_{4}\right]^{m}[\mathrm{NucOrg}]^{n}$, with $k_{\mathrm{NucOrg}}$ as a constant and $m$ and $n$ as integers (Zhang et al., 2012). NMINP was first proposed by Zhu et al. (2017) and assumed to be determined by the total consumed amount of $\mathrm{H}_{2} \mathrm{SO}_{4}$ vapor. This assumption was consistent with the huge measurements of banana-shaped NPF events reported in the literature (Kulmala et al., 2004) and can be supported by the rapid cessation of NPF after dozens of minutes with the rapid consumption of $\mathrm{H}_{2} \mathrm{SO}_{4}$ vapor (e.g., Fig. 1 in Yue et al., 2010 and Figs. 3 and 4 in Wang et al., 2011b). Regarding the high correlation between NMINP and FR, which is referred to as Scenario $1, \mathrm{H}_{2} \mathrm{SO}_{4}$ vapor should be relatively sufficient, while organic vapors are the limiting factor for the FR. Thus, the available organic vapor determines the FR, which affects the $\mathrm{H}_{2} \mathrm{SO}_{4}$ vapor that is used for NPF, and the total consumed $\mathrm{H}_{2} \mathrm{SO}_{4}$ vapor for NPF determines the NMINP. Therefore, the correlation between the NMINP and FR is established. In Scenario 2, which lacks correlation, the amount of organic vapors involved in nucleation and initial growth should be relatively sufficient relative to the $\mathrm{H}_{2} \mathrm{SO}_{4}$ vapor, leading to a larger FR. However, the NMINP is always determined by the total consumed $\mathrm{H}_{2} \mathrm{SO}_{4}$ vapor for NPF, although the consumed $\mathrm{H}_{2} \mathrm{SO}_{4}$ was determined by the consumed organic vapor in Scenario 1. Unsurprisingly, no correlation between the NMINP and FR was observed. Moreover, there was no significant difference between the CS under FR $>8 \mathrm{~cm}^{-3} \mathrm{~s}^{-1}$ and FR $\leq 8 \mathrm{~cm}^{-3} \mathrm{~s}^{-1}$. The removal of the newly formed particles cannot explain the presence and absence of correlations obtained above. However, the initial NPF times, defined as the time of $N_{<30} \mathrm{~nm}$ reaching the maximal value minus the time immediately before the apparent NPF was initiated, are significantly shorter under $F R>8 \mathrm{~cm}^{-3} \mathrm{~s}^{-1}$ than $\mathrm{FR} \leq 8 \mathrm{~cm}^{-3} \mathrm{~s}^{-1}$. The large FRs, i.e., larger than $8 \mathrm{~cm}^{-3} \mathrm{~s}^{-1}$, are most likely due to the organic-enhanced NPF. The FR threshold of $8 \mathrm{~cm}^{-3} \mathrm{~s}^{-1}$ and the slope of $3.9 \times 10^{3}$ were coincidentally consistent with our previous study, in which more observations in polluted continental atmospheres were included (i.e., Zhu et al., 2017). However, more observations worldwide and simultaneous measurements of organic vapors are required to confirm the hypotheses. No significant correlation between the NMINP and FR was obtained at the OUC site because of data limitations (Fig. S5a).

Because a size ceiling existed for the growth of new particles, we defined $D_{\text {pgmax }}$ to represent the maximum sizes of growing new particles. Among the total of $25 \mathrm{NPF}$ events over the marginal seas and NWPO, $D_{\text {pgmax }}$ was smaller than $50 \mathrm{~nm}$ on $24 \mathrm{NPF}$ days, except on a day when it was $77 \mathrm{~nm}$. As presented later, no clear increase in $N_{\mathrm{CCN}}$ could be identified when the $D_{\text {pg }}$ increased up to $77 \mathrm{~nm}$ at $\mathrm{SS}=0.2 \%$. At SS $=0.4 \%$, when $D_{\text {pg }}$ exceeded $50 \mathrm{~nm}, N_{\mathrm{CCN}}$ clearly increased with the $D_{\mathrm{pg}}$. Thus, we considered $50 \mathrm{~nm}$ as the CCN size under moderately high SS. A moderately linear correlation between $D_{\text {pgmax }}$ and GR in the daytime was obtained by excluding an outlier of $26 \mathrm{~nm} \mathrm{~h}^{-1}$ (Fig. 3b). Based on the obtained slope, newly formed particles could grow be- 

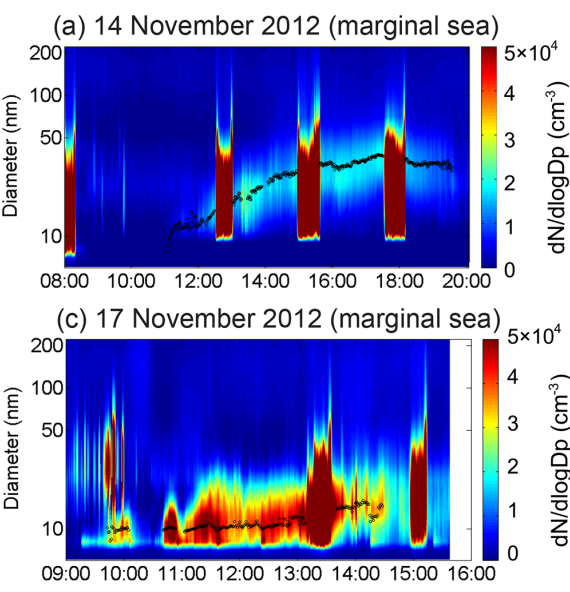

(b) 14 November 2012 (OUC)

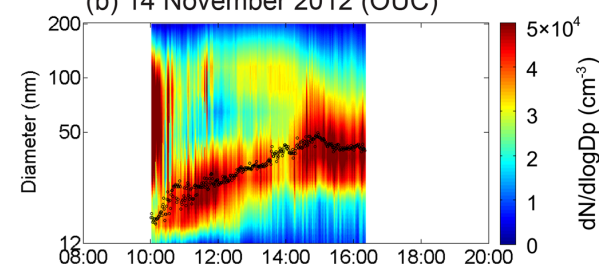

(d) 17 November 2012 (OUC)

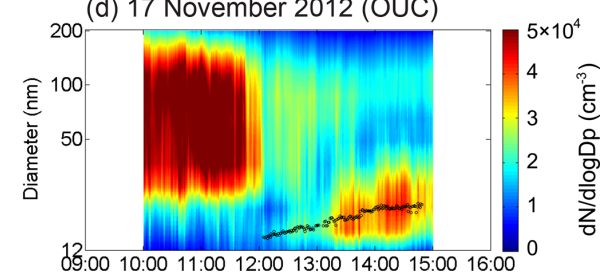

Figure 4. Class-I (a, b) and Class-II (c, d) NPF events in the atmosphere over the marginal seas of China and at the OUC site (the black dots represent $D_{\text {pg }}$ at 1 min time resolution, similar to the other contour plot figures).

yond $50 \mathrm{~nm}$ only when the GR exceeded $7.9 \mathrm{~nm} \mathrm{~h}^{-1}$ in the daytime. At the OUC site, a smaller GR $\left(4.8 \mathrm{~nm} \mathrm{~h}^{-1}\right)$ was required for new particles to grow to the $\mathrm{CCN}$ size, probably because of the longer survival time of new particles (Fig. S5b). The contribution of new particle growth to $\mathrm{CCN}$ size is presented in Sect. 4.3.

\subsection{Growth patterns of newly formed particles}

Two growth patterns (denoted as Class-I and Class-II) of newly formed particles were observed in the atmosphere over the marginal seas and NWPO as well as in the coastal atmosphere at the OUC site. Class-I NPF events were characterized by a typical banana-shaped growth pattern when $D_{\text {pg }}$ increased from approximately 10 to $20-100 \mathrm{~nm}$ in $0.5-$ $18 \mathrm{~h}$, which occurred on 16 days over the marginal seas and 13 days at the OUC site (e.g., Fig. 4a, b). For the Class-II NPF events, either no growth or the extremely low growth of newly formed particles was observed. The $D_{\text {pg }}$ remained invariant or slightly increased, but it was less than $20 \mathrm{~nm}$ until the number concentration of newly formed particles dropped to negligible levels (e.g., Fig. 4c, d). Compared to the ClassI NPF events, fewer Class-II events were observed in both marginal seas of China (7 days) and OUC (3 days). Over the NWPO, two NPF events were classified as Class-II because of the small $D_{\text {pgmax }}$ of $14 \mathrm{~nm}$, although large GRs were calculated.

Traditionally, Class-I NPF events occur on regional scales over a variety of atmospheres, such as forested areas, rural and urban areas, and even in heavily polluted regions (Kulmala and Kerminen, 2008; Kerminen et al., 2018), whereas Class-II NPF events are mostly local phenomena reported in a few studies over coastal areas (Wen et al., 2006; Vana et al., 2008; Ehn et al., 2010). In our previous study (Zhu et al., 2017), Class-II NPF events were observed in an urban atmosphere and further defined as a regional phenomenon instead of a local event. Thus, one of our objectives to design the parallel experiment over the marginal seas and the OUC was to confirm whether Class-II NPF events can regionally occur in the MBL and be observed at both environments. A total of seven Class-II NPF events were observed over the marginal seas (Fig. A1c, h, v, z, aa, ac, ah), and three NPF events can be observed concurrently at the OUC site (Fig. A1d, i, w). Moreover, these Class-II NPF events observed over the marginal seas lasted for more than $3 \mathrm{~h}$ in 6 days and were confirmed as regional events. Two of the three simultaneous NPF events at the OUC site were also Class-II (i.e., 12 and 17 November 2012, Fig. A1d, i), but the simultaneous NPF event at the OUC on 19 November 2013 (Fig. A1w) was a Class-I event. The distances between the two locations were 246, 243, and $467 \mathrm{~km}$ during these three events, and the air mass back trajectories indicated that the two locations were affected by large-scale regional air masses (Fig. S6b, e, 1).

The lack of apparent growth or extremely low growth of new particles during these Class-II NPF events implied that the particle growth appeared to be thermodynamically restricted. However, this limitation did not apply for the growth of $>10 \mathrm{~nm}$ particles in the Class-I events. On 19 November 2013, a Class-II event was observed over the marginal sea concurrently with a Class-I event at the OUC site, which could be explained by the thermodynamic restriction for the particle growth in the marine atmosphere, e.g., the vapor pressure of semi-volatile species in the atmosphere was less than the required value for gas-to-aerosol condensation. The particle growth in the coastal atmosphere implied that the vapor pressure of the semi-volatile species exceeded the required value and/or more less-volatile species were available to support the growth. Theoretically, a higher CS can remove more condensable vapors and consequently reduce the vapor pressure of precursors of various volatilities. In this case, the apparent particle growth was undetectable in the marine atmosphere, with the smaller CS of $0.6 \pm 0.1\left(10^{-2} \mathrm{~s}^{-1}\right)$ ver- 

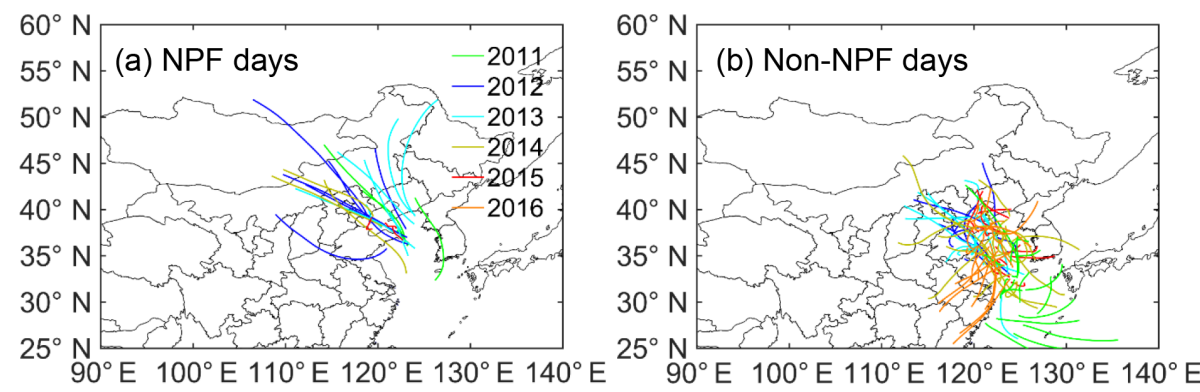

Figure 5. $24 \mathrm{~h}$ air mass back trajectories in the atmosphere over the marginal seas of China (the simulation time was the NPF initial time on NPF days and 08:00 LT - UTC + 8 - on non-NPF days).

sus the value of $5.3 \pm 0.2\left(10^{-2} \mathrm{~s}^{-1}\right)$ in the coastal atmosphere. However, the apparent growth of new particles at the OUC site indicated that (1) the concentrations of condensable vapors were higher than the required value to support the growth and (2) the CS was not the dominant factor that determined the growth. In addition to the condensation vapor, weather conditions can affect the growth of newly formed particles by changing gas-aerosol partitioning.

\section{Case studies and discussion}

\subsection{NPF events induced by ocean-derived precursors over the marginal seas of China}

During the spring and fall cruises over the marginal seas in 2011-2014, the $24 \mathrm{~h}$ back trajectories showed that air masses passed through areas with large emissions of air pollutants when NPF events occurred (Gao et al., 2011; Figs. 5a and S6). In contrast, during the summer cruises of 2015, the three observed NPF events were accompanied by air masses that were transported mainly from the marine atmosphere based on back trajectories (red lines in Figs. 5a, S6r, t, w). Among the three summer events, two passed through approximately the Shandong Peninsula, whereas a weak NPF event occurred on 30 August 2015 when the air mass almost completely originated from the marine atmosphere.

Here, we delve into the characteristics and evidence of oceanic precursors that were related to the NPF event on 30 August 2015. The transport pathway on that day is first magnified in Fig. 6a. As illustrated in Fig. 6b, the NPF event was first observed at 09:40 under meteorological conditions with an ambient temperature of $26^{\circ} \mathrm{C}$, high relative humidity of $74 \%$, and low wind speed of $1.5 \mathrm{~m} \mathrm{~s}^{-1}$ (not shown). During the first hour, the $N_{<30 \mathrm{~nm}}$ increased from $0.6 \times 10^{3} \mathrm{~cm}^{-3}$ to $1.7 \times 10^{3} \mathrm{~cm}^{-3}$. The weaker NPF was associated with a higher CS $\left(2 \times 10^{-2} \mathrm{~s}^{-1}\right)$. When the CS decreased to approximately $1 \times 10^{-2} \mathrm{~s}^{-1}$ after 11:00, $N_{<30 \mathrm{~nm}}$ sharply increased to $3 \times 10^{3} \mathrm{~cm}^{-3}$, and $D_{\text {pg }}$ increased from 13 to $18 \mathrm{~nm}$ over the following $3 \mathrm{~h}$ with a growth rate of $1.7 \mathrm{~nm} \mathrm{~h}^{-1}$. The signal of new particles disappeared at approximately 16:00. The overall NMINP was 5-20 times lower than all the other
NPF events over the marginal seas, and the overall FR of $0.3 \mathrm{~cm}^{-3} \mathrm{~s}^{-1}$ was the minimum in this study. To further support the marine source of this NPF event, one set of nanoMOUDI samples was collected during the period from 07:40 to 23:00 on that day. The mass concentrations of particulate dimethylaminium $\left(\mathrm{DMA}^{+}\right)$and trimethylaminium $\left(\mathrm{TMA}^{+}\right)$ were elevated within the small size range of $10-56 \mathrm{~nm}$ and might have contributed to the formation and growth of new particles to some extent (Fig. 6d). The observed high DMA ${ }^{+}$ and $\mathrm{TMA}^{+}$were very likely derived from oceanic sources, as reported by Hu et al. (2015) and Yu et al. (2016). Moreover, the simultaneously measured in situ subsurface chlorophyll maximum (SCM) of seawater as high as $3 \mathrm{mg} \mathrm{m}^{-3}$ during the NPF period also suggests strong biological activity in the sea zone. Overall, the NPF induced by oceanic precursors alone appeared to be much weaker than that by precursors from continents or a combination of both. For example, the observed oceanic particulate MSA in the marine atmosphere was about an order of magnitude smaller than particulate nss sulfate (Zhang et al., 2014).

\subsection{NPF events over the NWPO}

In the atmosphere over the NWPO, only two NPF events were observed on 8 and 13 April 2014 (Fig. 7). On 8 April 2014, the NPF event started to be observed at 07:43, and it lasted for $17 \mathrm{~min}$ (Fig. 7a, UTC + 10). The total particle number concentration increased from $0.6 \times 10^{4} \mathrm{~cm}^{-3}$ to a maximum value of $2.7 \times 10^{4} \mathrm{~cm}^{-3}$ during the NPF event, with an NMINP of $1.2 \times 10^{4} \mathrm{~cm}^{-3}$. The initial $D_{\mathrm{pg}}$ was approximately $8 \mathrm{~nm}$ and grew to $14 \mathrm{~nm}$ until the signal of new particles disappeared. The calculated FR and GR were $11.8 \mathrm{~cm}^{-3} \mathrm{~s}^{-1}$ and $26.3 \mathrm{~nm} \mathrm{~h}^{-1}$, higher than those of the NPF events over the marginal seas of China. In the marine atmosphere over open oceans, NPF events may occur aloft instead of near sea level (Wiedensohler et al., 1996; Clarke et al., 1998; Buzorius et al., 2004; Quinn and Bates, 2011; Meng et al., 2015). The high number concentration of new particles over the NWPO was likely caused by the downward effect of long-range upper-level continental transport, according to the following indirect evidence. First, the number concen- 

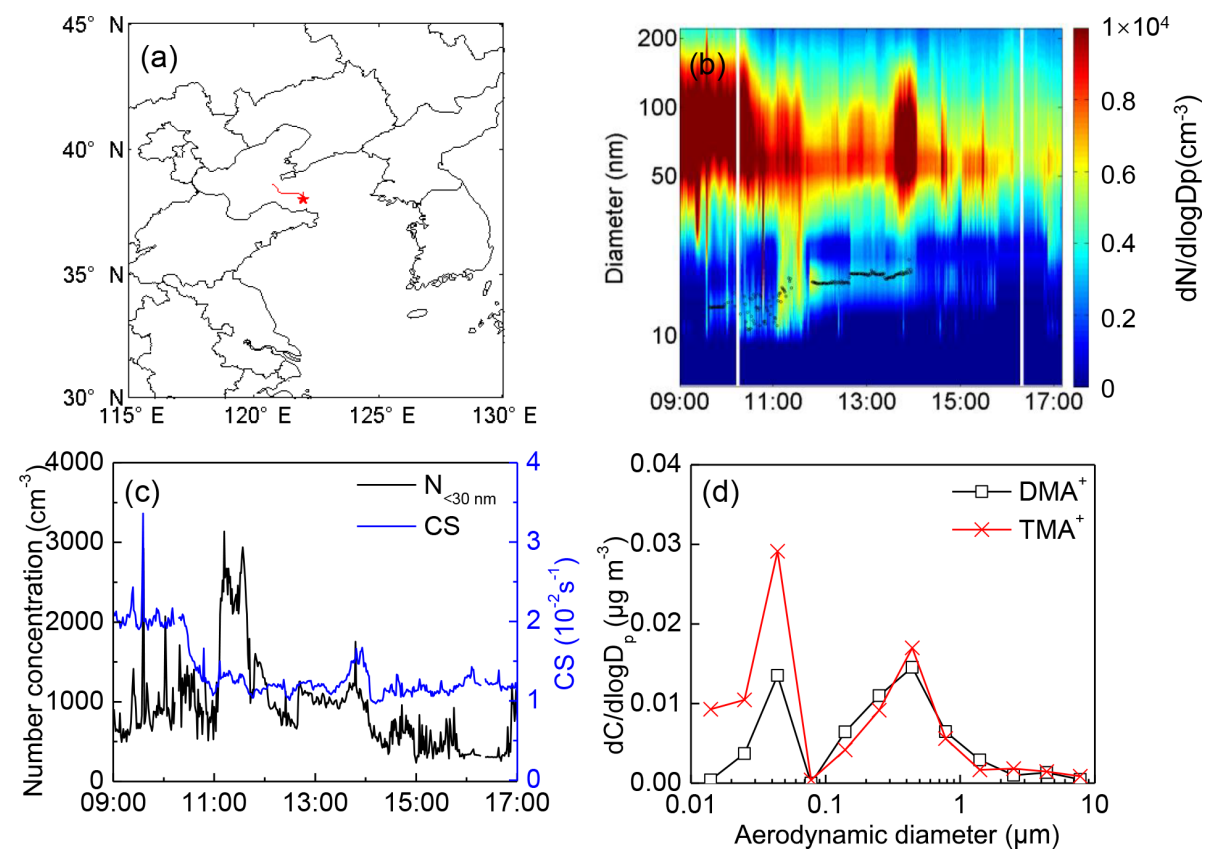

Figure 6. (a) $24 \mathrm{~h}$ air mass back trajectory,(b) contour plot of NPF events,(c) time series of $N_{<30 \mathrm{~nm}}$ and CS, and (d) size distributions of particulate $\mathrm{DMA}^{+}$and $\mathrm{TMA}^{+}$(sampling period was 07:44-21:15) on 30 August 2015.

trations of atmospheric particles larger than $30 \mathrm{~nm}$ reached $0.5-0.6 \times 10^{4} \mathrm{~cm}^{-3}$. The values were an order of magnitude larger than the clean marine background and approximately 2 times larger than the corresponding average values on nonNPF days (Category 1, as discussed in Sect. 3.2). In addition, the $24 \mathrm{~h}$ air mass back trajectory indicated that the air pollutant transport from the south of Japan had an altitude of $\sim 2000 \mathrm{~km}$ and then mixed downward (Figs. 7c and S7).

One set of MOUDI samples was collected during the period from 11:12 to 23:33. Although the sampling period had a delay of several hours against the NPF period on that day, the air mass back trajectories that swept over the oceanic zone were highly consistent between the two periods (Fig. S8). The concentrations of particulate chemical species were thereby used to argue the polluted extent of the air mass during these periods. The mass concentrations of nss sulfate and oxalate in particles smaller than $10 \mu \mathrm{m}$ were 1.9 and $0.12 \mu \mathrm{g} \mathrm{m}^{-3}$ (derived from Fig. 7d), respectively, higher than on other non-NPF days in this study. Previous studies, e.g., Mukai et al., (1995), Matsumoto et al. (1997), and Jung et al. (2014), reported that the mass concentration of nss sulfate was approximately $0.5 \mu \mathrm{g} \mathrm{m}^{-3}$ in the clean background over the NWPO. The elevated concentration of nss sulfate and oxalate on 8 April suggested enhanced anthropogenic precursor input, which very likely originated from the territory of Japan based on the calculated air mass back trajectories (Fig. 7c, d). The MOUDI data implied that the NPF event likely occurred in the air masses rich in anthropogenic precursors.

Compared to the above event on 8 April, the event on 13 April showed a longer NPF duration, lasting from 07:50 to approximately 08:50 (Fig. 7b). New particles signals were intermittently observed, and the FR was difficult to calculate. The total particle number concentrations increased from $0.3 \times 10^{4} \mathrm{~cm}^{-3}$ to a maximum of $2.6 \times 10^{4} \mathrm{~cm}^{-3}$ during the NPF event, and the NMINP was $1.4 \times 10^{4} \mathrm{~cm}^{-3} . D_{\text {pg }}$ increased from 8 to $14 \mathrm{~nm}$ in $1 \mathrm{~h}$, and the estimated GR was $3.6 \mathrm{~nm} \mathrm{~h}^{-1}$. One set of MOUDI samples was collected immediately after the event during the period from 09:10 to 21:05. Again, the calculated air mass back trajectories were consistent between the NPF period and the MOUDI sampling period (Fig. S8). The mass concentrations of nss sulfate and oxalate in particles smaller than $10 \mu \mathrm{m}$ were only 0.6 and $0.05 \mu \mathrm{g} \mathrm{m}^{-3}$. These values were close to the clean background of the NWPO, indicating much lower anthropogenic input on 13 April (Fig. 7e). Interestingly, the NMINP values were similar during the two NPF events, although the air mass on 8 April was polluted by anthropogenic inputs. However, the causes of these NPF events require further study because of lack of precursor vapor measurements.

\subsection{Growth of new particles to $\mathrm{CCN}$ size and the maximum survival probability}

Limited by the availability of $\mathrm{CCN}$ measurements in the marine atmosphere, there was only one NPF event on 4 September 2015 over the BS when the grown new particles were clearly identified to contribute to the $\mathrm{CCN}$ at $\mathrm{SS}=0.4 \%$ (Fig. 8a, b). This event was observed at an initially high relative humidity of $73 \%$. The total particle number concentration increased from $1.0 \times 10^{4} \mathrm{~cm}^{-3} \mathrm{~s}^{-1}$ to a maximum value 

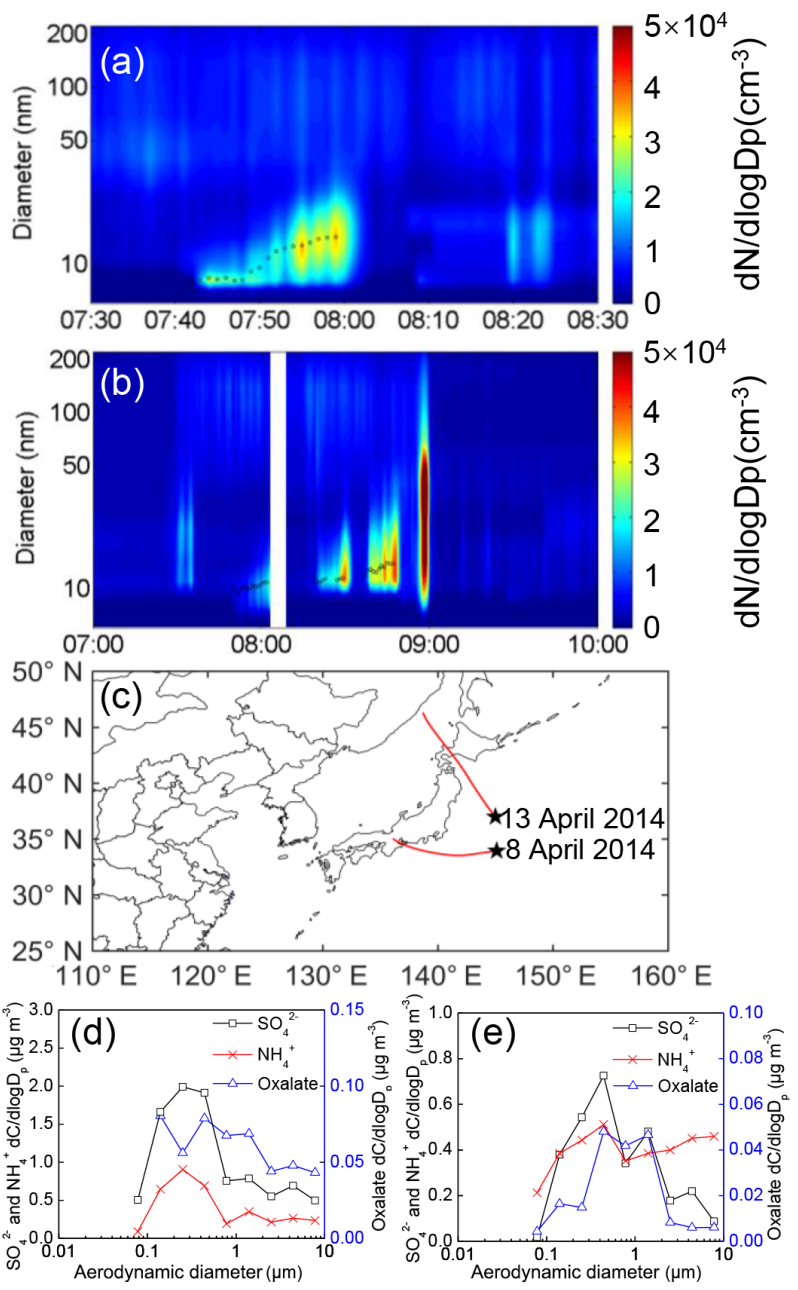

Figure 7. NPF events on 8 April 2014 (a) and 13 April 2014 (b), $24 \mathrm{~h}$ air mass back trajectories (c), and size distributions of particulate $\mathrm{SO}_{4}^{2-}, \mathrm{NH}_{4}^{+}$, and oxalate in mass concentration on 8 April 2014 (d) and 13 April 2014 (e) (sampling periods were 11:12-23:33 on 8 April 2014 and 09:10-21:05 on 13 April 2014).

of $4.5 \times 10^{4} \mathrm{~cm}^{-3} \mathrm{~s}^{-1}$ at $11: 12$, followed by a decrease to $2-$ $3 \times 10^{4} \mathrm{~cm}^{-3} \mathrm{~s}^{-1}$ in the next $3 \mathrm{~h}$ (solid line in Fig. 8c). At an SS of $0.4 \%$, the $D_{\text {pg }}$ increased from 19 to $50 \mathrm{~nm}$ during 10:40-13:10 (black circles in Fig. 8a), with the AR fluctuating at $0.1-0.2$ (Fig. 8c). After 13:10, the $D_{\text {pg }}$ increased from 50 to $77 \mathrm{~nm}$ with an increasing AR from $\sim 0.2$ to $\sim 0.4$. These results are consistent with those in the literature, i.e., particles smaller than $50 \mathrm{~nm}$ are unlikely to be activated as $\mathrm{CCN}$ at SS $=0.4 \%$ (Dusek et al., 2006; Petters and Kreidenweis, 2007). However, the contribution of grown new particles to $N_{\mathrm{CCN}}$ at $\mathrm{SS}=0.2 \%$ was unidentified. We then calculated $N_{>} D_{\mathrm{p}}\left(D_{\mathrm{p}}\right.$ was the particle diameter) when $D_{\mathrm{p}}$ varied from 50 to $200 \mathrm{~nm}$; for each $D_{\mathrm{p}}$, the values of $N_{>} D_{\mathrm{p}}$ were correlated with $N_{\mathrm{CCN}}$ at an SS of $0.4 \%$, and the desirable $D_{\mathrm{p}}$, which will be used below to calculate effective hygroscopicity parameters $(\kappa)$, had to satisfy a linear regression
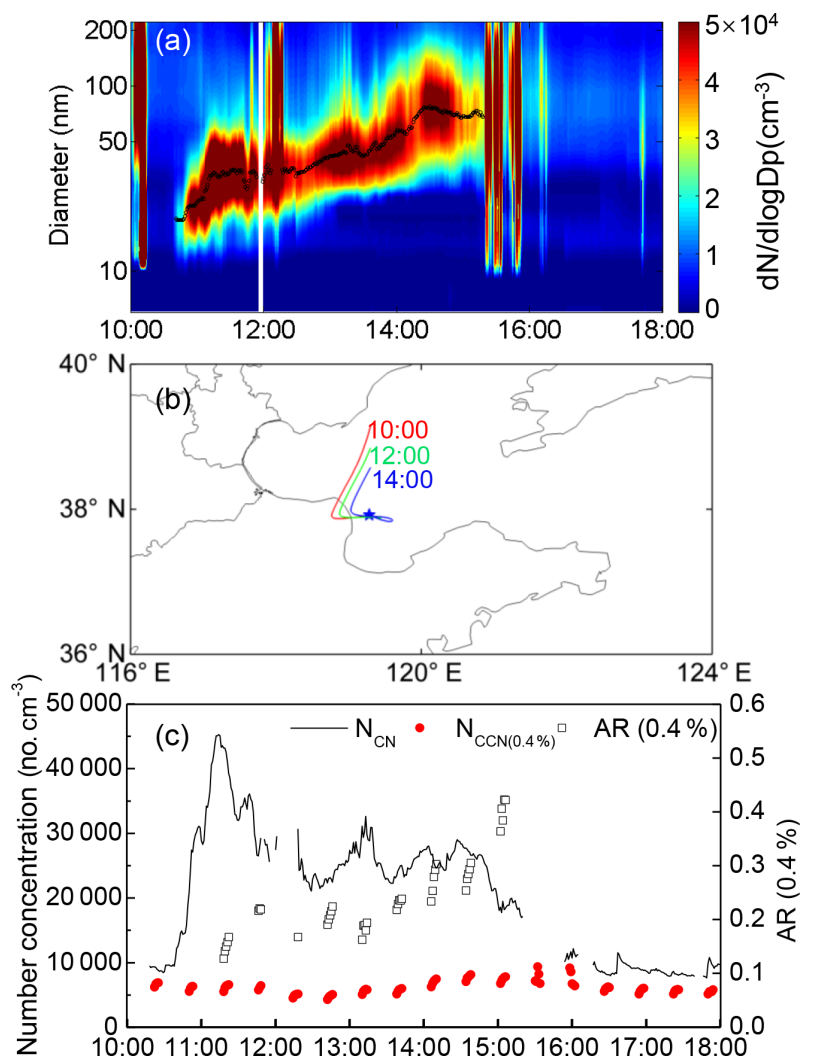

Figure 8. Contour plot of NPF event, $24 \mathrm{~h}$ air mass back trajectory throughout the NPF event, and the time series of the total particle number concentration $\left(N_{\mathrm{CN}}\right), \mathrm{CCN}$ number concentration at the SS of $0.4 \%\left(N_{\mathrm{CCN}(0.4)}\right)$, and $\mathrm{CCN}$ activation ratio (AR) on 4 September 2015 in BS.

slope close to 1 with relatively high correlation. In this case, we found that a $D_{\mathrm{p}}$ of $60 \mathrm{~nm}$ met these criteria during the initial NPF from 10:50 to 11:48. The subsequently calculated $\kappa$ was 0.40 , smaller than that of marine atmospheric aerosols $(\sim 0.7)$ but close to that of continental atmospheric aerosols ( 0.3; Pöschl et al., 2009; Rose et al., 2010), indicating the continental influence of this NPF event. The same method was applied to new particles that grew from 12:40 to 15:02, and a $D_{\mathrm{p}}$ value of 92.5 was identified to yield the best result (i.e., slope of 1.03 and $r=0.9$ ), with an estimated $\kappa$ as low as 0.1 , suggesting the condensation of organic vapors on the growing new particles (Yu, 2011; Riipinen et al., 2012).

To further evaluate the contribution of new particles to the $\mathrm{CCN}$, the maximum survival probability of new particles to CCN sizes (SP) was estimated as $N_{50 \mathrm{~nm}-(\mu+3 \sigma) \mathrm{nm} /} N_{<30 \mathrm{~nm}}$, where $\mu$ was the mean value and $\sigma$ was the standard deviation in the log-normal distribution of the new particle mode, and with $N_{50 \mathrm{~nm}-(\mu+3 \sigma) \mathrm{nm}}$ and $N_{<30 \mathrm{~nm}}$ referring to the maximum values during the event. In this case (4 September 2015), the SP was calculated to be 0.83 , implying that the majority of newly formed particles grew into $\mathrm{CCN}$ at $\mathrm{SS}=0.4 \%$. Following this approach, the estimated SP 
ranged from 0 to 0.29 , with an average value of 0.05 during the remaining 24 NPF events over the extended areas, including the marginal seas and NWPO. This low SP value suggests a low probability for the grown new particles to act as CCN. Moreover, there were 3 NPF days in the coastal atmosphere when the $D_{\text {pg }}$ grew to 70-100 nm (Fig. A1o, q, u). Unfortunately, simultaneous measurements of $\mathrm{CCN}$ were not available.

\subsection{Roles of amines and oxalic acid in growing new particles}

Oxidized organic compounds were widely identified to promote the growth of new particles, but most of these studies were restricted at the level of volatility and functional groups instead of the specific organic compounds (e.g., Wang et al., 2011a, 2015; Ehn et al., 2014; Patoulias et al., 2015). Numerous laboratory experiments and quantum chemical calculations have reported that amines play an important role in atmospheric nucleation and the growth of new particles (Zhang et al., 2012; Jen et al., 2014; Chen et al., 2015a, b, 2017; Olenius et al., 2017). Moreover, oxalic acid, one of the most abundant dicarboxylic acids, was proposed to be involved in NPF and was found to more readily bind to methylamine than ammonia (Guo et al., 2016; Arquero et al., 2017; Hong et al., 2018). Thus far, accurately measuring the mass concentrations of aminiums and oxalate in nucleation-mode particles has been challenging (Bzdek et al., 2013; Tao et al., 2016). During sampling with the nano-MOUDI in this study, the bounce-off effect could be very large when a rough estimation of the mass concentration of nanometer particles in three size bins of $10-56 \mathrm{~nm}$ using the particle number concentration from FMPS was compared with that using the sum of the ionic concentrations therein (not shown). The derived errors in the aminiums and oxalate in nanometer particles with aerodynamic diameters smaller than $56 \mathrm{~nm}$ were corrected by assuming that the observed $\mathrm{SO}_{4}^{2-}$ therein was completely attributed to the error. An appreciable amount of $\mathrm{SO}_{4}^{2-}$ should exist in $<56 \mathrm{~nm}$ particles, but this amount might be much smaller than sampling artifacts. The bounce-off error was thereby estimated by the concentration of $\mathrm{SO}_{4}^{2-}$ in nanometer particles by multiplying the highest ratios of aminium to $\mathrm{SO}_{4}^{2-}$ and oxalate to $\mathrm{SO}_{4}^{2-}$ in submicron-size bins, i.e., either $0.32-0.56 \mu \mathrm{m}$ or $0.56-1.0 \mu \mathrm{m}$, in samples from the same day. This comparison was also conducted for nanometer particles between 56-100 nm (not shown), and the mass fraction of the sum of ionic species to the estimated total mass was reasonably consistent with those in submicron particles, as reported in the literature. This result suggests that the error was minor.

Based on the above method, the aminium and oxalic acid were corrected for $18-56 \mathrm{~nm}$ particles. The mass fractions of aminiums and oxalate in 18-100 nm particles on NPF days for Class-I and Class-II events (discussed in Sect. 3.4) are shown in Fig. 9a-b. Here, we excluded the analysis of 10$18 \mathrm{~nm}$ particles because of the large underestimation of the particle number concentration of $<10 \mathrm{~nm}$ (mobility diameter) particles from the FMPS. In the Class-I NPF days, appreciable contributions from oxalate and $\mathrm{TMA}^{+}$to the total mass of the corresponding size particles were found in the size bins of $18-32 \mathrm{~nm}$ and $32-56 \mathrm{~nm}$, with oxalate 5-10 times higher than $\mathrm{TMA}^{+}$in each bin (Fig. 9a). For example, the mass concentration of oxalate in $18-32 \mathrm{~nm}$ particles was $10.0 \pm 10.0 \mathrm{ng} \mathrm{m}^{-3}$, accounting for $13 \% \pm 12 \%$ of the calculated particle mass concentration across the same size bin. In $32-56 \mathrm{~nm}$ and $56-100 \mathrm{~nm}$ particles, the mass concentration of oxalate was $10.9 \pm 8.2 \mathrm{ng} \mathrm{m}^{-3}$ and $5.8 \pm 2.4 \mathrm{ng} \mathrm{m}^{-3}$, accounting for $3 \% \pm 3 \%$ and $1.6 \% \pm 0.6 \%$ in each size bin, respectively. The mass fraction of $\mathrm{TMA}^{+}$was $5 \% \pm 8 \%$ in 18-32 nm particles (mass concentration of $2.4 \pm 1.9 \mathrm{ng} \mathrm{m}^{-3}$ ) but became minor in larger particles. In contrast, $\mathrm{DMA}^{+}$was undetectable in $18-32 \mathrm{~nm}$ and $56-100 \mathrm{~nm}$ particles. Appreciable $\mathrm{DMA}^{+}$was present in $32-56 \mathrm{~nm}$ particles, suggesting that $\mathrm{DMA}^{+}$might have been involved in the growth of these particles. On the Class-II days, the nanoparticles that we collected were pre-existing particles or were sourced from ocean emissions, rather than newly formed particles. To more directly compare the mass concentrations of the two species between the Class-I and Class-II NPF days, the absolute values are shown in Fig. 9c-d; notably, $30 \mathrm{Au}-$ gust 2015 was excluded because of the very high concentration of $\mathrm{TMA}^{+}$from oceanic precursors. The mass concentrations of $\mathrm{TMA}^{+}$and oxalate in $10-56 \mathrm{~nm}$ particles during the Class-I NPF days were significantly higher than that during the Class-II NPF days, suggesting appreciable contributions of trimethylamine (TMA) and oxalic acid to the growth of new particles.

\section{Conclusions}

During seven cruise campaigns over 165 observational days, a total of $25 \mathrm{NPF}$ events were observed in the atmospheres over the marginal seas of China and NWPO, and their occurrence frequency showed distinct seasonal characteristics, with the highest percentage of $28 \%$ in fall. The $24 \mathrm{~h}$ air mass back trajectories implied that 24 of the 25 NPF events might have been associated with the long-range transport of continental pollutants, which was supported by the number concentrations of pre-existing particles larger than $30 \mathrm{~nm}$, exceeding 1-2 orders of magnitude of the clean marine background values. Several pieces of indirect evidence implied that the remaining event, in which the NMINP was 5-20 times smaller, was very likely driven by oceanic precursors alone.

Over the NWPO, only two NPF events that last from $17 \mathrm{~min}$ to $1 \mathrm{~h}$ were observed in the remote marine atmosphere, but nucleation-mode particles were clearly detected during all 36 measurement days. However, the contribution of $N_{<30 \mathrm{~nm}}$ to the total particle number concentration reached $35 \% \pm 13 \%$ during the 36 measurement days, implying that 

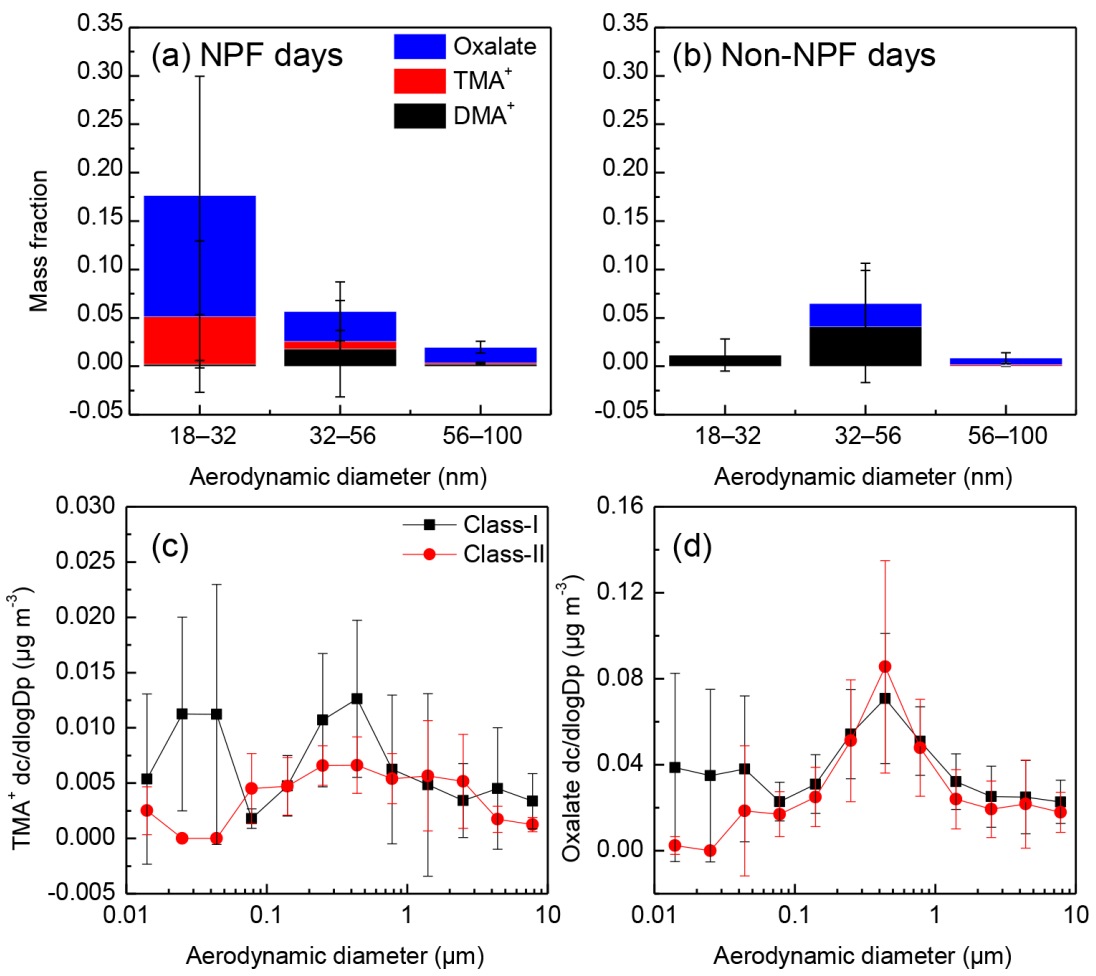

Figure 9. Average mass fraction of aminiums and oxalate in $18-30 \mathrm{~nm}, 32-56 \mathrm{~nm}$, and 56-100 nm particles on NPF days and non-NPF days, $(\mathbf{a}, \mathbf{b})$ and the average size distributions of $\mathrm{TMA}^{+}$and oxalate on Class-I and Class-II NPF days.

frequent NPF events may occur aloft, in the atmosphere over the NWPO. However, clear NPF events were observed in the sea-level atmosphere when certain criteria were satisfied, i.e., a strong downward transport of air masses during the initial period of NPF events.

Moderately good linear correlations were obtained between NMINP and FR and between $D_{\text {pgmax }}$ and GR. The threshold of the FRs was $8 \mathrm{~cm}^{-3} \mathrm{~s}^{-1}$, and $\mathrm{H}_{2} \mathrm{SO}_{4}$ vapor was argued to be relatively sufficient compared to organic vapors in NPF events at FR $\leq 8 \mathrm{~cm}^{-3} \mathrm{~s}^{-1}$. At FR $>8 \mathrm{~cm}^{-3} \mathrm{~s}^{-1}$, $\mathrm{H}_{2} \mathrm{SO}_{4}$ vapor was argued to be the limiting factor in terms of the net increase in the new particle number concentration, and organic vapors were argued to determine the FR.

We found that simultaneous measurements of the particle number concentration and $\mathrm{CCN}$ at different SS values can largely improve our understanding regarding the contribution of grown new particles to $\mathrm{CCN}$ and the chemicals that determine the growth of new particles to $\mathrm{CCN}$ size. For example, during the NPF event on 4 September $2015, N_{\mathrm{CCN}}$ clearly increased when $D_{\text {pg }}$ increased beyond $50 \mathrm{~nm}$ at an SS of $0.4 \%$. The calculated value of $\kappa$ decreased from 0.4 to 0.1 as new particles grew to $\mathrm{CCN}$ size, implying that organics likely overwhelmed this growth.

The simultaneous measurements in the atmosphere over the marginal seas and at the OUC site showed that simultaneous NPF events occurred on 12 days out of a total of 59 days. In the simultaneous NPF events, the NPF events over the marginal seas were characterized by larger FRs and comparable GRs. Three NPF events were observed over the marginal seas with no growth or extremely low growth, and the corresponding events at the OUC site showed no growth or extremely low growth on 2 days, while new particles showed obvious growth on 1 day. This lack of apparent growth or the extremely low growth of new particles in the marine atmospheres implies that semi-volatile species thermodynamically cannot support the growth of $>10 \mathrm{~nm}$ particles. When new particles showed obvious growth in the marine atmosphere, oxalate and $\mathrm{TMA}^{+}$occupied a significant proportion in $<56 \mathrm{~nm}$ particles, suggesting that TMA and oxalic acid might appreciably contribute to the growth of new particles. Direct measurements of these condensable vapors are required to confirm this hypothesis.

Data availability. The data of this paper are available upon request (contact: Yujiao Zhu, zhuyj@ ouc.edu.cn). 
Appendix A: General information on the NPF events
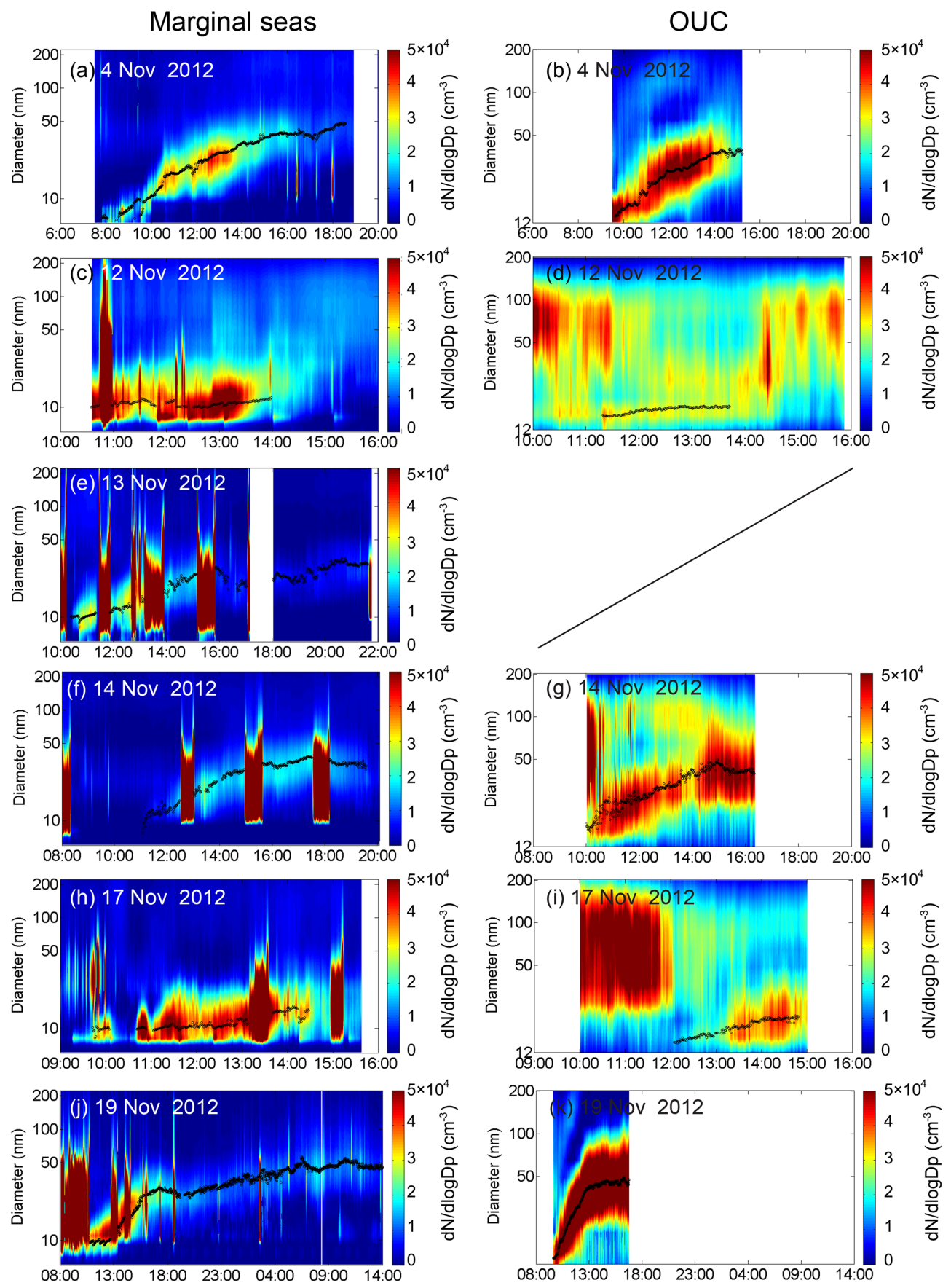

Figure A1. 

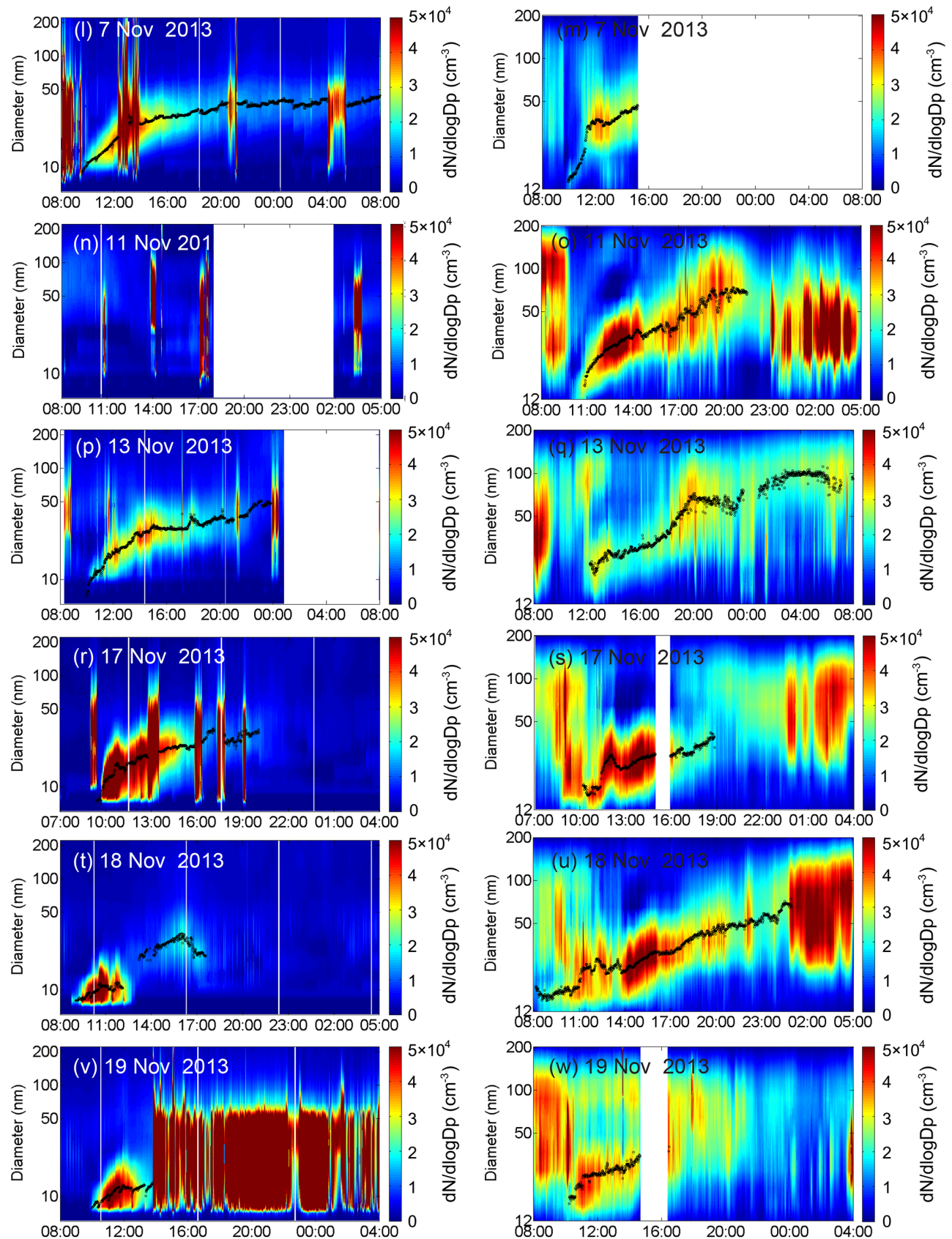

Figure A1. 

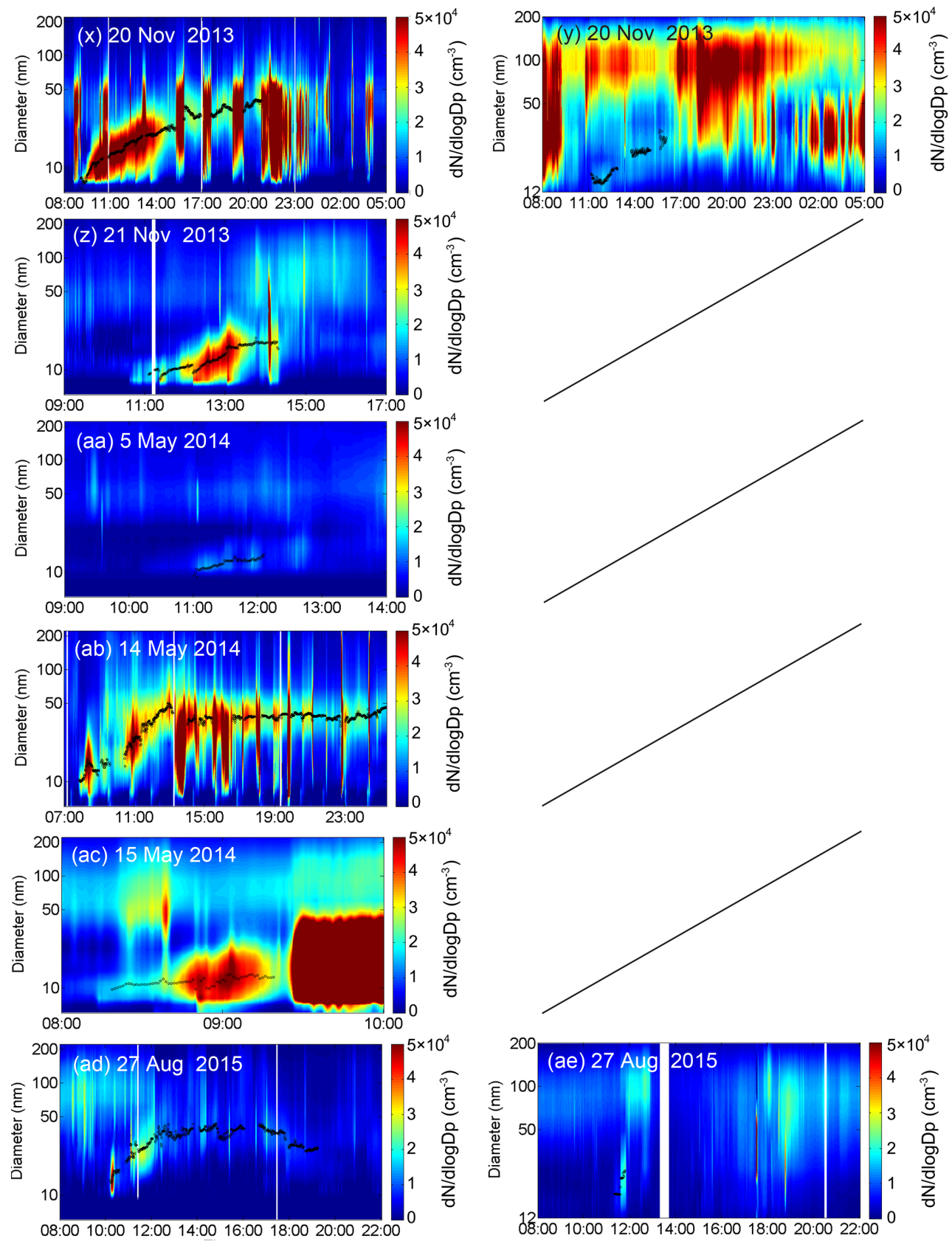

Figure A1. 

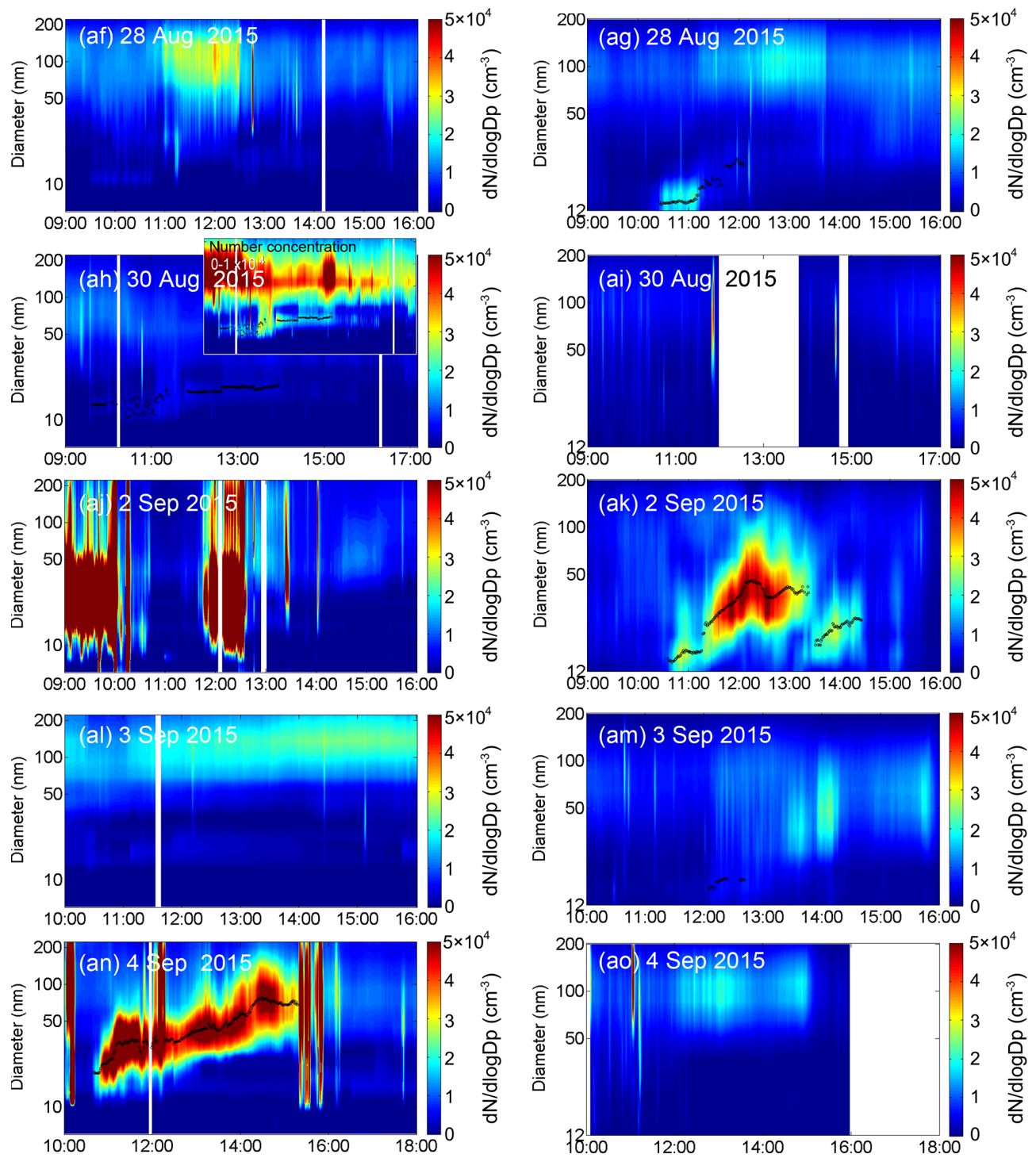

Figure A1. Contour plot of the NPF events in the atmosphere over the marginal seas of China and at the OUC site (the left-hand panels represent those over the marginal seas, and the right-hand panels represent the simultaneous measurement at the OUC site; the contour plot of the NPF events in 2011 can be found in Liu et al., 2014; no NPF events were observed during the cruise in 2016). 
Table A1. Characteristics of the NPF events in the atmosphere over the marginal seas of China (SYS, NYS, ECS, and BS), over NWPO, and at the OUC site. ST1-ST25 are marked in Fig. 1. Values in brackets within the body of the table represent particles with diameters larger than $10 \mathrm{~nm}$ that were used to calculate FRs for FMPS data when the parallel measurements were conducted.

\begin{tabular}{|c|c|c|c|c|c|c|c|c|}
\hline Date & Classification & Location & $\begin{array}{r}\mathrm{FR} \\
\left(\mathrm{cm}^{-3} \mathrm{~s}^{-1}\right)\end{array}$ & $\begin{array}{r}\text { GR } \\
\left(\mathrm{nm} \mathrm{h}^{-1}\right)\end{array}$ & $\begin{array}{r}\text { CS } \\
\left(10^{-2} \mathrm{~s}^{-1}\right)^{\mathrm{a}}\end{array}$ & $\begin{array}{l}\text { NMINP } \\
\left(\mathrm{cm}^{-3}\right)\end{array}$ & $\begin{array}{r}D_{\text {pgmax }} \\
(\mathrm{nm})\end{array}$ & $\begin{array}{r}\text { Survival } \\
\text { probability } \\
(\mathrm{SP})\end{array}$ \\
\hline 17 October $2011^{*}$ & Class-I & ST1 in SYS & $15.2 / 4.1$ & $2.5 / 7.5$ & $0.4 \pm 0.0$ & $\begin{array}{r}17490 / \\
14614\end{array}$ & $42 / 50$ & 0.03 \\
\hline 18 October $2011^{*}$ & Class-I & ST2 in SYS & 7.5 & 3.5 & - & 35909 & 28 & 0 \\
\hline 19 October $2011^{*}$ & Class-I & ST3 in SYS & $0.3 / 1.1$ & 3.4 & $0.7 \pm 0.0$ & $\begin{array}{l}438 / \\
3143\end{array}$ & 22 & 0 \\
\hline 26 October $2011^{*}$ & Class-I & ST4 in ECS & 1.6 & 4.4 & $0.6 \pm 0.0$ & 6691 & 21 & 0 \\
\hline \multirow[t]{2}{*}{4 November $2012^{*}$} & Class-I & ST5 in SYS & $1.4 / 3.1$ & $5.0 / 10.0$ & - & $\begin{array}{r}8627 / \\
14083\end{array}$ & $39 / 47$ & 0.10 \\
\hline & & OUC & - & 5.5 & - & - & 40 & 0.14 \\
\hline \multirow[t]{2}{*}{12 November 2012} & Class-II & ST6 in SYS & - & 0.2 & - & - & 12 & 0 \\
\hline & & OUC & 3.5 & 1 & $5.3 \pm 0.6$ & 4676 & 17 & 0 \\
\hline 13 November 2012 & Class-I & ST7 in SYS & 7.2 & $3.0 / 3.0$ & $1.1 \pm 0.0$ & 19916 & $28 / 34$ & 0 \\
\hline \multirow[t]{2}{*}{14 November 2012} & Class-I & ST8 in NYS & $1.1(0.71)$ & 4.4 & $0.3 \pm 0.1$ & 5588 & 38 & 0.2 \\
\hline & & OUC & 2.8 & 5.7 & $6.5 \pm 1.1$ & 7089 & 49 & 0.27 \\
\hline \multirow[t]{2}{*}{17 November 2012} & Class-II & ST9 in BS & $\begin{array}{r}3.2 / 18.8 \\
(2.3 / 16.4)\end{array}$ & 1.0 & $1.3 \pm 0.1$ & $\begin{array}{r}14420 / \\
19717\end{array}$ & 15 & 0 \\
\hline & & OUC & 2.7 & 3.1 & $7.5 \pm 1.3$ & 10518 & 20 & 0 \\
\hline \multirow[t]{2}{*}{19 November 2012} & Class-I & ST10 in BS & - & $4.5 / 1.7$ & - & - & $30 / 50$ & 0.16 \\
\hline & & OUC & 4.8 & 8.9 & - & 14248 & 49 & 0.6 \\
\hline \multirow[t]{2}{*}{7 November 2013} & Class-I & ST11 in SYS & $1.9(1.8)$ & 2.4 & - & 10458 & 42 & 0.09 \\
\hline & & OUC & 0.9 & 6 & $1.7 \pm 0.2$ & 6571 & 46 & 0.28 \\
\hline 11 November 2013 & Class-I & OUC & 1.8 & $5.4 / 6.0$ & $1.2 \pm 0.3$ & 12048 & $37 / 72$ & 1.12 \\
\hline \multirow[t]{2}{*}{13 November 2013} & Class-I & ST12 in SYS & $2.1(2.1)$ & $4.1 / 3.3$ & $1.1 \pm 0.1$ & 17005 & $30 / 49$ & 0.11 \\
\hline & & OUC & 2 & $2.3 / 6.9$ & $2.6 \pm 0.6$ & 10452 & $30 / 100$ & 1.76 \\
\hline \multirow[t]{2}{*}{17 November 2013} & Class-I & ST13 in NYS & $15.6(9.9)$ & $2.5 / 3.5$ & $0.5 \pm 0.0$ & 31391 & $32 / 32$ & 0 \\
\hline & & OUC & 2.6 & 2 & $4.2 \pm 0.8$ & 5458 & 38 & 0.06 \\
\hline \multirow[t]{2}{*}{18 November 2013} & Class-I & ST14 in NYS & $3.4(1.7)$ & 3.5 & $0.7 \pm 0.1$ & 22613 & 30 & 0.03 \\
\hline & & OUC & 2.2 & $2.0 / 3.9$ & $3.0 \pm 0.3$ & 12719 & $30 / 70$ & 0.56 \\
\hline \multirow[t]{2}{*}{19 November 2013} & Class-I/II & ST15 in NYS (II) & $3.8(2.3)$ & 1.1 & $0.6 \pm 0.1$ & 23886 & 12 & 0 \\
\hline & & OUC (I) & 2.3 & 3 & $5.3 \pm 0.2$ & 10556 & 40 & 0 \\
\hline \multirow[t]{2}{*}{20 November 2013} & Class-I & ST16 in NYS & $6.6(4.3)$ & 2.8 & $0.8 \pm 0.1$ & 28818 & 40 & 0.03 \\
\hline & & OUC & 1.3 & 3.5 & $3.4 \pm 0.1$ & 3032 & 28 & 0 \\
\hline 21 November 2013 & Class-II & ST17 in BS & 3.2 & 3.4 & $1.2 \pm 0.2$ & 24845 & 17 & 0 \\
\hline
\end{tabular}

a: condensation sink (CS) that was averaged $1 \mathrm{~h}$ prior to the nucleation event. *: data from Liu et al., 2014. 
Table A1. Continued.

\begin{tabular}{|c|c|c|c|c|c|c|c|c|}
\hline Date & Classification & Location & $\begin{array}{r}\mathrm{FR} \\
\left(\mathrm{cm}^{-3} \mathrm{~s}^{-1}\right)\end{array}$ & $\begin{array}{r}\mathrm{GR} \\
\left(\mathrm{nm} \mathrm{h}^{-1}\right)\end{array}$ & $\begin{array}{r}\text { CS } \\
\left(10^{-2} \mathrm{~s}^{-1}\right)^{\mathrm{a}}\end{array}$ & $\begin{array}{l}\text { NMINP } \\
\left(\mathrm{cm}^{-3}\right)\end{array}$ & $\begin{array}{r}D_{\text {pgmax }} \\
(\mathrm{nm})\end{array}$ & $\begin{array}{r}\text { Survival } \\
\text { probability } \\
(\mathrm{SP})\end{array}$ \\
\hline 5 May 2014 & Class-II & ST18 in SYS & 2.5 & 3.3 & $1.7 \pm 0.2$ & 4163 & 14 & 0 \\
\hline 14 May 2014 & Class-I & ST19 in BS & 8.8 & 6.7 & $1.7 \pm 0.4$ & 31545 & 50 & 0.29 \\
\hline 15 May 2014 & Class-II & ST20 in BS & 8.3 & 2.5 & $2.5 \pm 0.2$ & 25746 & 13 & 0 \\
\hline \multirow[t]{2}{*}{27 August 2015} & Class-I & ST21 in SYS & $18.5(13.3)$ & 9.6 & $3.5 \pm 0.5$ & 18930 & 41 & 0.05 \\
\hline & & OUC & 3.2 & 16.2 & $1.4 \pm 0.1$ & 6720 & 25 & 0 \\
\hline 28 August 2015 & Class-I & OUC & 2.1 & 8.0 & $1.3 \pm 0.2$ & 4873 & 26 & 0 \\
\hline 30 August 2015 & Class-II & ST22 in NYS & 0.3 & 1.7 & $2.1 \pm 0.2$ & 1450 & 19 & 0 \\
\hline 2 September 2015 & Class-I & OUC & $6.7 / 3.5$ & $20.3 / 9$ & $1.2 \pm 0.2$ & $\begin{array}{r}9034 / \\
2915\end{array}$ & $45 / 26$ & 0.91 \\
\hline 3 September 2015 & Class-II & OUC & 0.5 & 3.2 & $0.8 \pm 0.1$ & 1847 & 18 & 0 \\
\hline 4 September 2015 & Class-I & ST23 in BS & 12.7 & 10.6 & $2.5 \pm 0.0$ & 22355 & 77 & 0.83 \\
\hline 8 April 2014 & Class-II & ST24 in NWPO & 11.8 & 26.3 & $1.9 \pm 0.2$ & 11709 & 14 & 0 \\
\hline 13 April 2014 & Class-II & ST25 in NWPO & - & 3.6 & $0.6 \pm 0.1$ & - & 14 & 0 \\
\hline
\end{tabular}

a: Condensation sink (CS) was averaged $1 \mathrm{~h}$ prior to the nucleation event. *: data from Liu et al., 2014. 
Supplement. The supplement related to this article is available online at: https://doi.org/10.5194/acp-19-89-2019-supplement.

Author contributions. XY and HG designed the experiment. YZ, $\mathrm{KL}, \mathrm{YS}$, and $\mathrm{XL}$ conducted the cruise campaigns and field measurements. YZ wrote the paper. XY, YG, and YY provided advice on data processing. All authors contributed toward revising and improving the paper.

Competing interests. The authors declare that they have no conflict of interest.

Acknowledgements. The authors thank the support from the National Key Research and Development Program in China (No. 2016YFC0200504), National Natural Science Foundation of China (No. 41706122 and 41473088), and the Fundamental Research Funds for the Central Universities (NO. 201762010).

Edited by: Veli-Matti Kerminen

Reviewed by: two anonymous referees

\section{References}

Allan, J. D., Williams, P. I., Najera, J., Whitehead, J. D., Flynn, M. J., Taylor, J. W., Liu, D., Darbyshire, E., Carpenter, L. J., Chance, R., Andrews, S. J., Hackenberg, S. C., and McFiggans, G.: Iodine observed in new particle formation events in the Arctic atmosphere during ACCACIA, Atmos. Chem. Phys., 15, 55995609, https://doi.org/10.5194/acp-15-5599-2015, 2015.

Arquero, K. D., Gerber, R. B., and Finlayson-Pitts, B. J.: The role of oxalic acid in new particle formation from methanesulfonic acid, methylamine, and water, Environ. Sci. Technol., 51, 2124-2130, https://doi.org/10.1021/acs.est.6b05056, 2017.

Ayers, G. P. and Gras, J. L.: Seasonal relationship between cloud condensation nuclei and aerosol methanesulphonate in marine air, Nature, 353, 834-835, https://doi.org/10.1038/353834a0, 1991.

Buzorius, G., McNaughton, C. S., Clarke, A. D., Covert, D. S., Blomquist, B., Nielsen, K., and Brechtel, F. J.: Secondary aerosol formation in continental outflow conditions during ACE-Asia, J. Geophys. Res., 109, D24203, https://doi.org/10.1029/2004JD004749, 2004.

Bzdek, B. R., Horan, A. J., Pennington, M. R., DePalma, J. W., Zhao, J., Jen, C. N., Hanson, D. R., Smith, J. N., McMurry, P. H., and Johnston, M. V.: Quantitative and time-resolved nanoparticle composition measurements during new particle formation, Faraday Discuss., 165, 25-43, https://doi.org/10.1039/C3FD00039G, 2013.

Chang, R. Y. W., Sjostedt, S. J., Pierce, J. R., Papakyriakou, T. N., Scarratt, M. G., Michaud, S., Levasseur, M., Leaitch, W. R., and Abbatt, J. P.: Relating atmospheric and oceanic DMS levels to particle nucleation events in the Canadian Arctic, J. Geophys. Res., 116, D17, https://doi.org/10.1029/2011JD015926, 2011.

Charlson, R. J., Lovelock, J. E, Andreae, M. O., and Warren, S. G.: Oceanic phytoplankton, atmospheric sulfur, cloud albedo and cli- mate, Nature, 326, 655-661, https://doi.org/10.1038/326655a0, 1987.

Chen, H. and Finlayson-Pitts, B. J.: New Particle Formation from Methanesulfonic Acid and Amines/Ammonia as a Function of Temperature, Environ. Sci. Technol., 51, 243-252, https://doi.org/10.1021/acs.est.6b04173, 2017.

Chen, H., Ezell, M. J., Arquero, K. D., Varner, M. E., Dawson, M. L., Gerber, R. B., and Finlayson-Pitts, B. J.: New particle formation and growth from methanesulfonic acid, trimethylamine and water, Phys. Chem. Chem. Phys., 17, 13699-13709, https://doi.org/10.1039/c5cp00838g, 2015a.

Chen, H., Varner, M. E., Gerber, R. B., and Finlayson-Pitts, B. J.: Reactions of methanesulfonic acid with amines and ammonia as a source of new particles in air, J. Phys. Chem. B, 120, 15261536, https://doi.org/10.1021/acs.jpcb.5b07433, 2015 b.

Cho, Y. K., Kim, M. O., and Kim, B. C.: Sea Fog around the Korean Peninsula, J. Appl. Meteorol., $39, \quad 2473-2479, \quad$ https://doi.org/10.1175/15200450(2000)039<2473:SFATKP>2.0.CO;2, 2000.

Covert, D. S., Kapustin, V. N., Bates, T. S., and Quinn, P. K.: Physical properties of marine boundary layer aerosol particles of the mid-Pacific in relation to sources and meteorological transport, J. Geophys. Res., 101, 6919-6930, https://doi.org/10.1029/95JD03068, 1996.

Clarke, A. D., Varner, J. L., Eisele, F., Mauldin, R. L., Tanner, D., and Litchy, M.: Particle production in the remote marine atmosphere: Cloud outflow and subsidence during ACE-1, J. Geophys. Res., 103, 16397-16409, https://doi.org/10.1029/97JD02987, 1998.

Dal Maso, M., Kulmala, M., Riipinen, I., Wagner, R., Hussein, T., Aalto, P. P., and Lehtinen, K. E. J.: Formation and growth of fresh atmospheric aerosols: Eight years of aerosol size distribution data from SMEAR II, Hyytiala, Finland, Boreal Environ. Res., 10, 323-336, 2005.

Dusek, U., Frank, G. P., Hildebrandt, L., Curtius, J., Schneider, J., Walter, S., Chand, D., Drewnick, F., Hings, S., Jung, D., Borrmann, S., and Andreae, M. O: Size matters more than chemistry for cloud-nucleating ability of aerosol particles, Science, 312, 1375-1378, https://doi.org/10.1126/science.1125261, 2006.

Ehn, M., Vuollekoski, H., Petäjä, T., Kerminen, V.-M., Vana, M., Aalto, P., Leeuw, de G., Ceburnis, D., Dupuy, R., O’Dowd, C. D., and Kulmala, M.: Growth rates during coastal and marine new particle formation in western Ireland, J. Geophys. Res., 115, D18218, https://doi.org/10.1029/2010JD014292, 2010.

Ehn, M., Thornton, J. A., Kleist, E., Sipilä, M., Junninen, H., Pullinen, L., Springer, M., Rubach, F., Tillmann, R., Lee, B., LopezHilfiker, F., Andres, S., Acir, I.-H., Rissanen, M., Jokinen, T., Schobesberger, S., Kangasluoma, J., Kontkanen, J., Nieminen, T., Kurtén, T., Nielsen, L. B., Jørgensen, S., Kjaergaard, G. H., Canagaratna, M., Dal Maso, M., Berndt, T., Petäjä, T., Wahner, A., Kerminen, V.-M., Kulmala, M., Worsnop, D. R., Wildt, J., and Mentel, T. F.: A large source of lowvolatility secondary organic aerosol, Nature, 506, 476-4479, https://doi.org/10.1038/nature13032, 2014.

Gao, H., Chen, J., Wang, B., Tan, S. C., Lee, C. M., Yao, X., Yan, H., and Shi, J.: A study of air pollution of city clusters, Atmos. Environ., 45, 3069-3077, https://doi.org/10.1016/j.atmosenv.2011.03.018, 2011. 
Ge, X., Wexler, A. S., and Clegg, S. L.: Atmospheric amines - part I. A review, Atmos. Environ., 45, 524-546, https://doi.org/10.1016/j.atmosenv.2010.10.012, 2011.

Guo, T., Li, K., Zhu, Y., Gao, H., and Yao, X.: Concentration and size distribution of particulate oxalate in marine and coastal atmospheres-Implication for the increased importance of oxalate in nanometer atmospheric particles, Atmos. Environ., 142, 1931, https://doi.org/10.1016/j.atmosenv.2016.07.026, 2016.

Hegg, D. A., Ferek, R. J., Hobbs, P. V., and Radke, L. F.: Dimethyl sulfide and cloud condensation nucleus correlations in the northeast Pacific Ocean, J. Geophys. Res., 96, 13189-13191, https://doi.org/10.1029/91JD01309, 1991.

Hirsikko, A., Bergman, T., Laakso, L., Dal Maso, M., Riipinen, I., Hõrrak, U., and Kulmala, M.: Identification and classification of the formation of intermediate ions measured in boreal forest, Atmos. Chem. Phys., 7, 201-210, https://doi.org/10.5194/acp-7201-2007, 2007.

Hong, Y., Liu, Y. R., Wen, H., Miao, S. K., Huang, T., Peng, X. Q., Jiang, S., Feng, Y. J., and Huang, W.: Interaction of oxalic acid with methylamine and its atmospheric implications, RSC Adv., 8, 7225-7234, https://doi.org/10.1039/C7RA13670F, 2018.

Hoppel, W. A., Frick, G. M. and Larson, R. E.: Effect of nonprecipitating clouds on the aerosol size distribution in the marine boundary layer, Geophys. Res. Lett., 13, 125-128, https://doi.org/10.1029/GL013i002p00125, 1986.

Hoppel, W. A., Frick, G. M., and Fitzgerald, J. W.: Deducing droplet concentration and supersaturation in marine boundary layer clouds from surface aerosol measurements, J. Geophys. Res., 101, 26553-26565, https://doi.org/10.1029/96JD02243, 1996.

Hu, Q., Yu, P., Zhu, Y., Li, K., Gao, H., and Yao, X.: Concentration, size distribution, and formation of trimethylaminium and dimethylaminium ions in atmospheric particles over marginal seas of China, J. Atmos. Sci., 72, 3487-3498, https://doi.org/10.1175/JAS-D-14-0393.1, 2015.

Huang, R. J., Seitz, K., Neary, T., O’Dowd, C. D., Platt, U., and Hoffmann, T.: Observations of high concentrations of $\mathrm{I}_{2}$ and $\mathrm{IO}$ in coastal air supporting iodine-oxide driven coastal new particle formation, Geophys. Res. Lett., 37, L03803, https://doi.org/10.1029/2009GL041467, 2010.

Hussein, T., Junninen, H., Tunved, P., Kristensson, A., Dal Maso, M., Riipinen, I., Aalto, P. P., Hansson, H.-C., Swietlicki, E., and Kulmala, M.: Time span and spatial scale of regional new particle formation events over Finland and Southern Sweden, Atmos. Chem. Phys., 9, 4699-4716, https://doi.org/10.5194/acp-9-46992009, 2009.

Jen, C. N., McMurry, P. H., and Hanson, D. R.: Stabilization of sulfuric acid dimers by ammonia, methylamine, dimethylamine, and trimethylamine, J. Geophys. Res.-Atmos., 119, 7502-7514, https://doi.org/10.1002/2014JD021592, 2014.

Jeong, C.-H., Evans, G. J., McGuire, M. L., Chang, R. Y.-W., Abbatt, J. P. D., Zeromskiene, K., Mozurkewich, M., Li, S.M., and Leaitch, W. R.: Particle formation and growth at five rural and urban sites, Atmos. Chem. Phys., 10, 7979-7995, https://doi.org/10.5194/acp-10-7979-2010, 2010.

Jung, J., Furutani, H., Uematsu, M., Park, J.: Distributions of atmospheric non-sea-salt sulfate and methanesulfonic acid over the Pacific Ocean between $48^{\circ} \mathrm{N}$ and $55^{\circ} \mathrm{S}$ during summer, Atmos. Environ., 99, 374-384, https://doi.org/10.1016/j.atmosenv.2014.10.009, 2014.
Kalkavouras, P., Bossioli, E., Bezantakos, S., Bougiatioti, A., Kalivitis, N., Stavroulas, I., Kouvarakis, G., Protonotariou, A. P., Dandou, A., Biskos, G., Mihalopoulos, N., Nenes, A., and Tombrou, M.: New particle formation in the southern Aegean Sea during the Etesians: importance for $\mathrm{CCN}$ production and cloud droplet number, Atmos. Chem. Phys., 17, 175-192, https://doi.org/10.5194/acp-17-175-2017, 2017.

Kazil, J., Stier, P., Zhang, K., Quaas, J., Kinne, S., O’Donnell, D., Rast, S., Esch, M., Ferrachat, S., Lohmann, U., and Feichter, J.: Aerosol nucleation and its role for clouds and Earth's radiative forcing in the aerosol-climate model ECHAM5-HAM, Atmos. Chem. Phys., 10, 10733-10752, https://doi.org/10.5194/acp-1010733-2010, 2010.

Kerminen, V.-M., Paramonov, M., Anttila, T., Riipinen, I., Fountoukis, C., Korhonen, H., Asmi, E., Laakso, L., Lihavainen, H., Swietlicki, E., Svenningsson, B., Asmi, A., Pandis, S. N., Kulmala, M., and Petäjä, T.: Cloud condensation nuclei production associated with atmospheric nucleation: a synthesis based on existing literature and new results, Atmos. Chem. Phys., 12, 12037 12059, https://doi.org/10.5194/acp-12-12037-2012, 2012.

Kerminen, V. M., Chen, X., Vakkari, V., Petäjä, T., Kulmala, M., and Bianchi, F.: Atmospheric new particle formation and growth: review of field observations, Environ. Res. Lett., 13, 103003, https://doi.org/10.1088/1748-9326/aadf3c, 2018.

Khlystov, A., Stanier, C., and Pandis, S. N.: An algorithm for combining electrical mobility and aerodynamic size distributions data when measuring ambient aerosol special issue of aerosol science and technology on findings from the fine particulate matter supersites program, Aerosol Sci. Technol., 38, 229-238, https://doi.org/10.1080/02786820390229543, 2004.

Kulmala, M. and Kerminen, V. M.: On the formation and growth of atmospheric nanoparticles, Atmos. Res., 90, 132-150, https://doi.org/10.1016/j.atmosres.2008.01.005, 2008.

Kulmala, M., Vehkamäki, H., Petäjä, T., Dal Maso, M., Lauri, A., Kerminen, V. M., Birmili, W., and McMurry, P. H.: Formation and growth rates of ultrafine atmospheric particles: a review of observations, J. Aerosol Sci., 35, 143-176, https://doi.org/10.1016/j.jaerosci.2003.10.003, 2004.

Kulmala, M., Petäjä, T., Nieminen, T., Sipilä, M., Manninen, H. E., Lehtipalo, K., Dao Maso, M., Aalto, P. P., Junninen, H., Paasonen, P., Riipinen, I., Lehtinen, K. E. J., Laaksonen, A., and Kerminen, V-M.: Measurement of the nucleation of atmospheric aerosol particles, Nat. Protoc., 7, 1651-1667, https://doi.org/10.1038/nprot.2012.091, 2012.

Lana, A., Simó, R., Vallina, S. M., and Dachs, J.: Potential for a biogenic influence on cloud microphysics over the ocean: a correlation study with satellite-derived data, Atmos. Chem. Phys., 12, 7977-7993, https://doi.org/10.5194/acp-12-7977-2012, 2012.

Lee, B. P., Li, Y. J., Flagan, R. C., Lo, C., and Chan, C. K.: Sizing characterization of the fast mobility particle sizer (FMPS) against SMPS and HR-ToF-AMS, Aerosol Sci. Technol., 47, 1030 1037, https://doi.org/10.1080/02786826.2013.810809, 2013.

Liu, X. H., Zhu, Y. J., Zheng, M., Gao, H. W., and Yao, X. H.: Production and growth of new particles during two cruise campaigns in the marginal seas of China, Atmos. Chem. Phys., 14, 7941-7951, https://doi.org/10.5194/acp-14-7941-2014, 2014.

Luo, L., Kao, S.-J., Bao, H., Xiao, H., Xiao, H., Yao, X., Gao, H., Li, J., and Lu, Y.: Sources of reactive nitrogen in marine aerosol over 
the Northwest Pacific Ocean in spring, Atmos. Chem. Phys., 18, 6207-6222, https://doi.org/10.5194/acp-18-6207-2018, 2018.

Man, H., Zhu, Y., Ji, F., Yao, X., Lau, N. T., Li, Y. J., Lee, B. P., and Chan, C. K.: Comparison of daytime and nighttime new particle growth at the HKUST Supersite in Hong Kong, Environ. Sci. Technol., 49, 7170-7178, https://doi.org/10.1021/acs.est.5b02143, 2015.

Matsumoto, K., Tanaka, H., Nagao, I., and Ishizaka, Y.: Contribution of particulate sulfate and organic carbon to cloud condensation nuclei in the marine atmosphere, Geophys. Res. Lett., 24, 655-658, https://doi.org/10.1029/97GL00541, 1997.

McFiggans, G., Bale, C. S. E., Ball, S. M., Beames, J. M., Bloss, W. J., Carpenter, L. J., Dorsey, J., Dunk, R., Flynn, M. J., Furneaux, K. L., Gallagher, M. W., Heard, D. E., Hollingsworth, A. M., Hornsby, K., Ingham, T., Jones, C. E., Jones, R. L., Kramer, L. J., Langridge, J. M., Leblanc, C., LeCrane, J.-P., Lee, J. D., Leigh, R. J., Longley, I., Mahajan, A. S., Monks, P. S., Oetjen, H., Orr-Ewing, A. J., Plane, J. M. C., Potin, P., Shillings, A. J. L., Thomas, F., von Glasow, R., Wada, R., Whalley, L. K., and Whitehead, J. D.: Iodine-mediated coastal particle formation: an overview of the Reactive Halogens in the Marine Boundary Layer (RHaMBLe) Roscoff coastal study, Atmos. Chem. Phys., 10, 2975-2999, https://doi.org/10.5194/acp10-2975-2010, 2010.

Meng, H., Zhu, Y., Evans, G. J., and Yao, X.: An approach to investigate new particle formation in the vertical direction on the basis of high time-resolution measurements at ground level and sea level, Atmos. Environ., 102, 366-375, https://doi.org/10.1016/j.atmosenv.2014.12.016, 2015.

Mukai, H., Yokouchi, Y., and Suzuki, M.: Seasonal variation of methanesulfonic acid in the atmosphere over the oki islands in the sea of Japan, Atmos. Environ., 29, 1637-1648, https://doi.org/10.1016/1352-2310(95)00057-6, 1995.

Nieminen, T., Kerminen, V.-M., Petäjä, T., Aalto, P. P., Arshinov, M., Asmi, E., Baltensperger, U., Beddows, D. C. S., Beukes, J. P., Collins, D., Ding, A., Harrison, R. M., Henzing, B., Hooda, R., Hu, M., Hõrrak, U., Kivekäs, N., Komsaare, K., Krejci, R., Kristensson, A., Laakso, L., Laaksonen, A., Leaitch, W. R., Lihavainen, H., Mihalopoulos, N., Németh, Z., Nie, W., O’Dowd, C., Salma, I., Sellegri, K., Svenningsson, B., Swietlicki, E., Tunved, P., Ulevicius, V., Vakkari, V., Vana, M., Wiedensohler, A., Wu, Z., Virtanen, A., and Kulmala, M.: Global analysis of continental boundary layer new particle formation based on longterm measurements, Atmos. Chem. Phys., 18, 14737-14756, https://doi.org/10.5194/acp-18-14737-2018, 2018.

O'Dowd, C. D. and de Leeuw, G.: Marine aerosol production: A review of the current knowledge, Philos. T. Roy. Soc. A, 365, 1753-1774, https://doi.org/10.1098/rsta.2007.2043, 2007.

O’Dowd, C. D., Jimenez, J. L., Bahreini, R., Flagan, R. C., Seinfeld, J. H., Hämeri, K., Pirjola, L., Kulmala, M., Jennings, S. G., and Hoffmann, T.: Marine aerosol formation from biogenic iodine emissions, Nature, 417, 632-636, https://doi.org/10.1038/nature00775, 2002a.

O’Dowd, C. D., Hämeri, K., Mäkelä, J. M., Pirjola, L., Kulmala, M., Jennings, S. G., Berresheim, H., Hansson, H-C., de Leeuw, G., Kunz, G. J., Allen, A. G., Hewitt, C. N., Jackson, A., Viisanen, Y., and Hoffmann, T.: A dedicated study of new particle formation and fate in the coastal environment (PARFORCE): overview of objectives and achievements, J. Geophys. Res., 107, D19, https://doi.org/10.1029/2001JD000555, 2002b.

Olenius, T., Halonen, R., Kurtén, T., Henschel, H., KupiainenMäättä, O., Ortega, I. K., Jen, C. N., Vehkamäki, H., and Riipinen, I.: New particle formation from sulfuric acid and amines: Comparison of monomethylamine, dimethylamine, and trimethylamine, J. Geophys. Res.-Atmos., 122, 7103-7118, https://doi.org/10.1002/2017JD026501, 2017.

Paasonen, P., Nieminen, T., Asmi, E., Manninen, H. E., Petájá, T., Plass-Dúlmer, C., Flentje, H., Birmili, W., Wiedensohler, A., Hõrrak, U., Metzger, A., Hamed, A., Laaksonen, A., Facchini, M. C., Kerminen, V.-M., and Kulmala, M.: On the roles of sulphuric acid and low-volatility organic vapours in the initial steps of atmospheric new particle formation, Atmos. Chem. Phys., 10, 11223-11242, https://doi.org/10.5194/acp-10-112232010, 2010.

Patoulias, D., Fountoukis, C., Riipinen, I., and Pandis, S. N.: The role of organic condensation on ultrafine particle growth during nucleation events, Atmos. Chem. Phys., 15, 6337-6350, https://doi.org/10.5194/acp-15-6337-2015, 2015.

Peng, J. F., Hu, M., Wang, Z. B., Huang, X. F., Kumar, P., Wu, Z. J., Guo, S., Yue, D. L., Shang, D. J., Zheng, Z., and He, L. Y.: Submicron aerosols at thirteen diversified sites in China: size distribution, new particle formation and corresponding contribution to cloud condensation nuclei production, Atmos. Chem. Phys., 14, 10249-10265, https://doi.org/10.5194/acp-14-102492014, 2014.

Petters, M. D. and Kreidenweis, S. M.: A single parameter representation of hygroscopic growth and cloud condensation nucleus activity, Atmos. Chem. Phys., 7, 1961-1971, https://doi.org/10.5194/acp-7-1961-2007, 2007.

Pikridas, M., Riipinen, I., Hildebrandt, L., Kostenidou, E., Manninen, H., Mihalopoulos, N., Kalivitis, N., Burkhart, J. F., Stohl, A., Kulmala, M., and Pandis, S. N.: New particle formation at a remote site in the eastern Mediterranean, J. Geophys. Res., 117, D12205, https://doi.org/10.1029/2012JD017570, 2012.

Pöschl, U., Rose, D., and Andreae, M. O.: Climatologies of cloud related aerosols. Part 2: Particle hygroscopicity and cloud condensation nuclei activity, MIT Press, Cambridge, 5872, https://doi.org/10.7551/mitpress/9780262012874.001.0001, 2009.

Quinn, P. K. and Bates, T. S.: The case against climate regulation via oceanic phytoplankton sulphur emissions, Nature, 480, 5156, https://doi.org/10.1038/nature10580, 2011.

Riipinen, I., Yli-Juuti, T., Pierce, J. R., Petäjä, T., Worsnop, D. R., Kulmala, M., and Donahue, N. M.: The contribution of organics to atmospheric nanoparticle growth, Nat. Geosci., 5, 453-458, https://doi.org/10.1038/ngeo1499, 2012.

Roach, W. T.: Back to basics: Fog. Part 3 - the formation and dissipation of sea fog, Weather, 50, 80-84, 1995.

Rose, D., Nowak, A., Achtert, P., Wiedensohler, A., Hu, M., Shao, M., Zhang, Y., Andreae, M. O., and Pöschl, U.: Cloud condensation nuclei in polluted air and biomass burning smoke near the mega-city Guangzhou, China - Part 1: Size-resolved measurements and implications for the modeling of aerosol particle hygroscopicity and CCN activity, Atmos. Chem. Phys., 10, 33653383, https://doi.org/10.5194/acp-10-3365-2010, 2010.

Sabaliauskas, K., Jeong, C-H., Yao, X., Jun, Y-S., Jadidian, P., and Evans, G. J.: Five-Year Roadside Measurements of Ultrafine Par- 
ticles in a Major Canadian City, Atmos. Environ., 49, 245-256, https://doi.org/10.1016/j.atmosenv.2011.11.052, 2012.

Seinfeld, J. H. and Pandis, S. N.: Atmospheric chemistry and physics: from air pollution to climate change, John Wiley \& Sons, New York, 2012.

Sellegri, K., Pey, J., Rose, C., Culot, A., DeWitt, H. L., Mas, S., Schwier, A. N., Temime-Roussel, B., Charriere, B., SaizLopez, A., Mahajan, A. S., Parin, D., Kukui, A., Sempere, R., Anna, B. D., and Marchand, N.: Evidence of atmospheric nanoparticle formation from emissions of marine microorganisms, Geophys. Res. Lett., 43, 6596-6603, https://doi.org/10.1002/2016GL069389, 2016.

Shen, X., Sun, J., Kivekäs, N., Kristensson, A., Zhang, X., Zhang, Y., Zhang, L., Fan, R., Qi, X., Ma, Q., and Zhou, H.: Spatial distribution and occurrence probability of regional new particle formation events in eastern China, Atmos. Chem. Phys., 18, 587599, https://doi.org/10.5194/acp-18-587-2018, 2018.

Sipilä, M., Sarnela, N., Jokinen, T., Henschel, H., Junninen, H., Kontkanen, J., Richters, S., Kangasluoma, J., Franchin, A., Peräkylä, O., Rissanen, M., Ehn, M., Vehkamäki, H., Kurten, T., Berndt, T., Petäjä, T., Worsnop, D., Ceburnis, D., Kerminen, V.M., Kulmala, M., and O'Dowd, C.: Molecular-scale evidence of aerosol particle formation via sequential addition of $\mathrm{HIO}_{3}, \mathrm{Na}-$ ture, 537, 532-534, https://doi.org/10.1038/nature19314, 2016.

Sorooshian, A., Padro, L. T., Nenes, A., Feingold, G., McComiskey, A., Hersey, S. P., Gates, H., Jonsson, H. H., Miller, S. D., Stephens, G. L., Flagan, R. C., and Seinfeld, J. H.: On the link between ocean biota emissions, aerosol, and maritime clouds: Airborne, ground, and satellite measurements off the coast of California, Global Biogeochem. Cy., 23, GB4007, https://doi.org/10.1029/2009GB003464, 2009.

Tao, Y., Ye, X., Jiang, S., Yang, X., Chen, J., Xie, Y., and Wang, R.: Effects of amines on particle growth observed in new particle formation events, J. Geophys. Res., 121, 324-335, https://doi.org/10.1002/2015JD024245, 2016.

Teng, X., Hu, Q., Zhang, L., Qi, J., Shi, J., Xie, H., Gao, H. W., and Yao, X.: Identification of major sources of atmospheric $\mathrm{NH}_{3}$ in an urban environment in northern China during wintertime, Environ. Sci. Technol., 51, 6839-6848, https://doi.org/10.1021/acs.est.7b00328, 2017.

Ueda, S., Miura, K., Kawata, R., Furutani, H., Uematsu, M., Omori, Y., and Tanimoto, H.: Number-size distribution of aerosol particles and new particle formation events in tropical and subtropical Pacific Oceans, Atmos. Environ., 142, 324-339, https://doi.org/10.1016/j.atmosenv.2016.07.055, 2016.

Vana, M., Ehn, M., Petäjä, T., Vuollekoski, H., Aalto, P., de Leeuw, G., Ceburnisc, D., O'Dowd, C. D., and Kulmala, M.: Characteristic features of air ions at Mace Head on the west coast of Ireland, Atmos. Res., 90, 278-286, https://doi.org/10.1016/j.atmosres.2008.04.007, 2008.

Wang, L., Xu, W., Khalizov, A. F., Zheng, J., Qiu, C., and Zhang, R.: Laboratory investigation on the role of organics in atmospheric nanoparticle growth, J. Phys. Chem. A, 115, 8940-8947, https://doi.org/10.1021/jp1121855, 2011a.

Wang, Z., Wu, Z., Yue, D., Shang, D., Guo, S., Sun, J., Ding, A., Wang, L., Jiang, J., Guo, H., Gao, J., Cheung, H. C., Morawska, L., Keywood, M., and Hu, M.: New particle formation in China: Current knowledge and further directions, Sci. Total Environ.,
577, 258-266, https://doi.org/10.1016/j.scitotenv.2016.10.177, 2017.

Wang, Z. B., Hu, M., Yue, D. L., Zheng, J., Zhang, R. Y., Wiedensohler, A., Wu, Z. J., Nieminen, T., and Boy, M.: Evaluation on the role of sulfuric acid in the mechanisms of new particle formation for Beijing case, Atmos. Chem. Phys., 11, 12663-12671, https://doi.org/10.5194/acp-11-12663-2011, 2011 b.

Wang, Z. B., Hu, M., Sun, J. Y., Wu, Z. J., Yue, D. L., Shen, X. J., Zhang, Y. M., Pei, X. Y., Cheng, Y. F., and Wiedensohler, A.: Characteristics of regional new particle formation in urban and regional background environments in the North China Plain, Atmos. Chem. Phys., 13, 12495-12506, https://doi.org/10.5194/acp-13-12495-2013, 2013.

Wang, Z. B., Hu, M., Pei, X. Y., Zhang, R. Y., Paasonen, P., Zheng, J., Yue, D. L., Wu, Z. J., Boy, M., and Wiedensohler, A.: Connection of organics to atmospheric new particle formation and growth at an urban site of Beijing, Atmos. Environ., 103, 7-17, https://doi.org/10.1016/j.atmosenv.2014.11.069, 2015.

Wen, J., Zhao, Y., and Wexler, A. S.: Marine particle nucleation: observations at Bodega Bay, California, J. Geophys. Res., 111, D08207, https://doi.org/10.1029/2005JD006210, 2006.

Wiedensohler, A., Covert, D. S., Swietlicki, E., Aalto, P., Heintzenberg, J., and Leck, C.: Occurrence of an ultrafine particle mode less than $20 \mathrm{~nm}$ in diameter in the marine boundary layer during Arctic summer and autumn, Tellus B, 48, 213-222, https://doi.org/10.1034/j.1600-0889.1996.t01-1-00006.x, 1996.

Yao, X. H., Chio, M. Y., Lau, N. T., Lau, A. P. S., Chan, C. K., and Fang, M.: Growth and shrinkage of new particles in the atmosphere in Hong Kong, Aerosol Sci. Tech., 44, 639-650, https://doi.org/10.1080/02786826.2010.482576, 2010.

Yu, F.: A secondary organic aerosol formation model considering successive oxidation aging and kinetic condensation of organic compounds: global scale implications, Atmos. Chem. Phys., 11, 1083-1099, https://doi.org/10.5194/acp-11-1083-2011, 2011.

Yu, F. and Luo, G.: Oceanic dimethyl sulfide emission and new particle formation around the coast of Antarctica: a modeling study of seasonal variations and comparison with measurements, Atmosphere, 1, 34-50, https://doi.org/10.3390/atmos1010034, 2010.

Yu, P., Hu, Q., Li, K., Zhu, Y., Liu, X., Gao, H., and Yao, X.: Characteristics of dimethylaminium and trimethylaminium in atmospheric particles ranging from supermicron to nanometer sizes over eutrophic marginal seas of China and oligotrophic open oceans, Sci. Total Environ., 572, 813-824, https://doi.org/10.1016/j.scitotenv.2016.07.114, 2016.

Yue, D. L., Hu, M., Zhang, R. Y., Wang, Z. B., Zheng, J., Wu, Z. J., Wiedensohler, A., He, L. Y., Huang, X. F., and Zhu, T.: The roles of sulfuric acid in new particle formation and growth in the mega-city of Beijing, Atmos. Chem. Phys., 10, 4953-4960, https://doi.org/10.5194/acp-10-4953-2010, 2010.

Zhang, R., Khalizov, A., Wang, L., Hu, M., and Xu, W.: Nucleation and growth of nanoparticles in the atmosphere, Chem. Rev., 112, 1957-2011, https://doi.org/10.1021/cr2001756, 2012.

Zhang, S. H., Yang, G. P., Zhang, H. H., and Yang, J.: Spatial variation of biogenic sulfur in the south Yellow Sea and the East China Sea during summer and its contribution to atmospheric sulfate aerosol, Sci. Total Environ., 488, 157-167, https://doi.org/10.1016/j.scitotenv.2014.04.074, 2014. 
Zhu, Y., Sabaliauskas, K., Liu, X., Meng, H., Gao, H., Jeong, C. H., Evans, G. J., and Yao, X.: Comparative analysis of new particle formation events in less and severely polluted urban atmosphere, Atmos. Environ., 98, 655-664, https://doi.org/10.1016/j.atmosenv.2014.09.043, 2014.

Zhu, Y., Yan, C., Zhang, R., Wang, Z., Zheng, M., Gao, H., Gao, Y., and Yao, X.: Simultaneous measurements of new particle formation at $1 \mathrm{~s}$ time resolution at a street site and a rooftop site, Atmos. Chem. Phys., 17, 9469-9484, https://doi.org/10.5194/acp17-9469-2017, 2017.
Zimmerman, N., Jeong, C. H., Wang, J. M., Ramos, M., Wallace, J. S., and Evans, G. J.: A source-independent empirical correction procedure for the fast mobility and engine exhaust particle sizers, Atmos. Environ., 100, 178-184, https://doi.org/10.1016/j.atmosenv.2014.10.054, 2015. 